\title{
Mobile Sorption-based Thermal Battery for Harvesting Low-Temperature Geothermal Energy
}

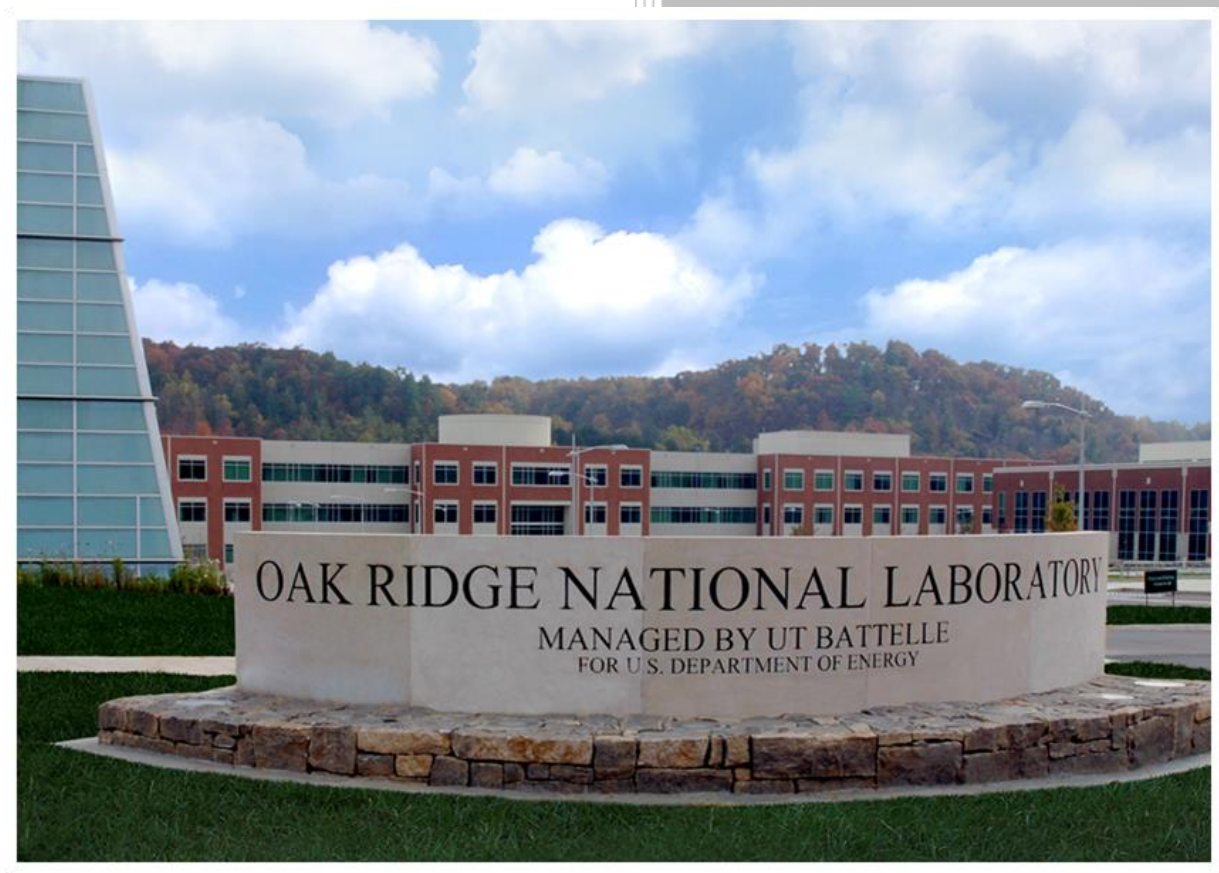

Lingshi Wang

Xiaobing Liu

Zhiyao Yang

Kyle Gluesenkamp

August 2020 


\title{
DOCUMENT AVAILABILITY
}

Reports produced after January 1, 1996, are generally available free via US Department of Energy (DOE) SciTech Connect.

Website www.osti.gov

Reports produced before January 1, 1996, may be purchased by members of the public from the following source:

\author{
National Technical Information Service \\ 5285 Port Royal Road \\ Springfield, VA 22161 \\ Telephone 703-605-6000 (1-800-553-6847) \\ TDD 703-487-4639 \\ Fax 703-605-6900 \\ E-mail info@ntis.gov \\ Website http://classic.ntis.gov/
}

Reports are available to DOE employees, DOE contractors, Energy Technology Data Exchange representatives, and International Nuclear Information System representatives from the following source:

Office of Scientific and Technical Information

PO Box 62

Oak Ridge, TN 37831

Telephone 865-576-8401

Fax 865-576-5728

E-mail reports@osti.gov

Website http://www.osti.gov/contact.html

This report was prepared as an account of work sponsored by an agency of the United States Government. Neither the United States Government nor any agency thereof, nor any of their employees, makes any warranty, express or implied, or assumes any legal liability or responsibility for the accuracy, completeness, or usefulness of any information, apparatus, product, or process disclosed, or represents that its use would not infringe privately owned rights. Reference herein to any specific commercial product, process, or service by trade name, trademark, manufacturer, or otherwise, does not necessarily constitute or imply its endorsement, recommendation, or favoring by the United States Government or any agency thereof. The views and opinions of authors expressed herein do not necessarily state or reflect those of the United States Government or any agency thereof. 
Energy and Transportation Science Division

\title{
MOBILE SORPTION-BASED THERMAL BATTERY FOR HARVESTING LOW- TEMPERATURE GEOTHERMAL ENERGY
}

\author{
Lingshi Wang \\ Xiaobing Liu \\ Zhiyao Yang \\ Kyle Gluesenkamp
}

Date Published:

August 2020

Prepared by

OAK RIDGE NATIONAL LABORATORY

Oak Ridge, TN 37831-6283

managed by

UT-BATTELLE, LLC

for the

US DEPARTMENT OF ENERGY

under contract DE-AC05-00OR22725 



\section{ACKNOWLEDGMENTS}

This work was sponsored by the U. S. Department of Energy's Geothermal Technologies Office under Contract No. DE-AC05-00OR22725 with UT-Battelle, LLC. The authors would also like to acknowledge Joshua Mengers, Technology Manager, National Laboratory Impact Initiative, and Arlene Anderson, Technology Development Manager, Geothermal Technologies Program, U.S. Department of Energy Geothermal Technologies Office. The authors would also like to thank Anthony Gehl and Neal Durfee for their assistance in experimental setup and evaluation. 


\section{CONTENTS}

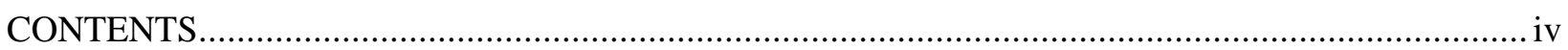

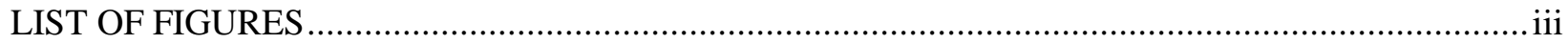

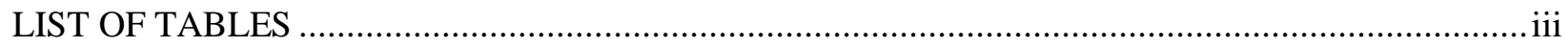

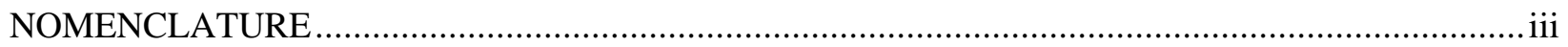

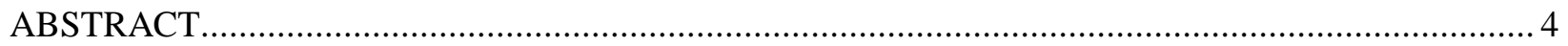

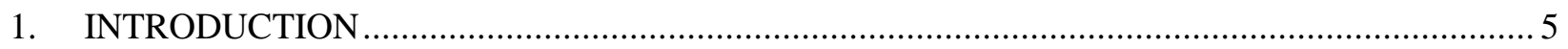

2. PROTOTYPE OF MOBILE SORPTION-BASED THERMAL BATTERY …............................ 7

3. EXPERIMENTAL APPARATUS FOR CHARACTERIZING MSTB …............................... 9

3.1 EXPERIMENTAL APPARATUS AND TEST PROCEDURE ..................................... 9

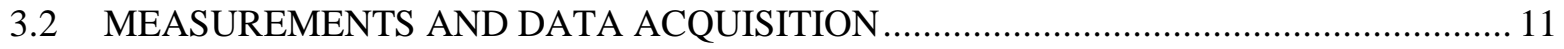

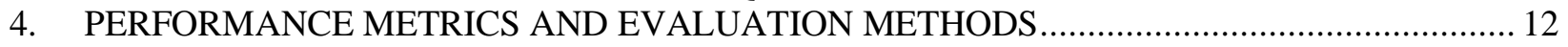

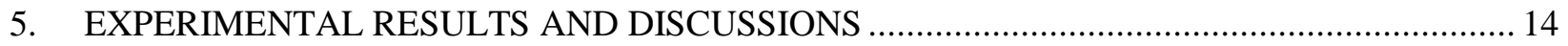

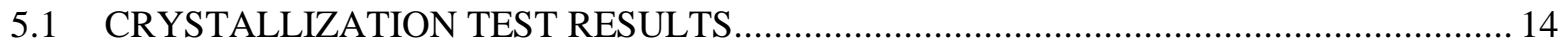

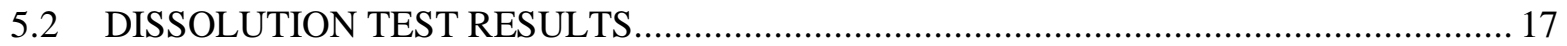

6. A PARAMETRIC STUDY OF CRYSTALLIZATION AND DISSOLUTION …........................ 19

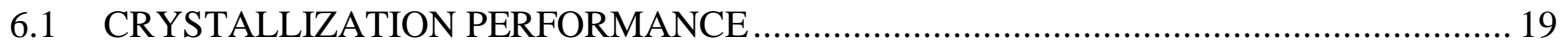

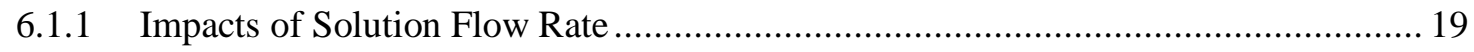

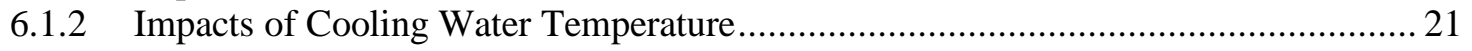

6.1.3 Comparison of Energy Storage Density with Other Thermal Storage

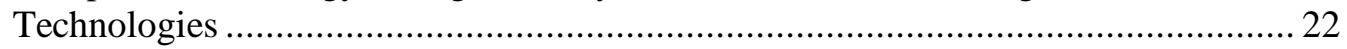

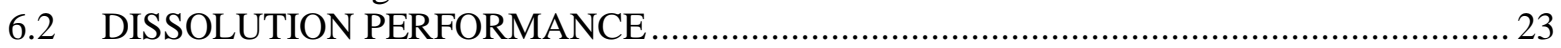

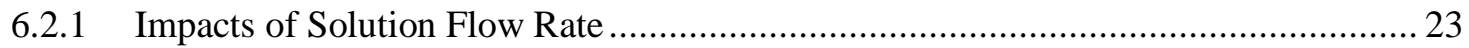

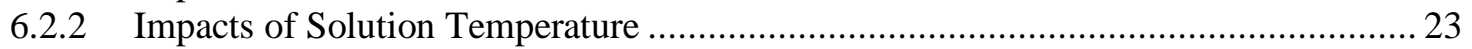

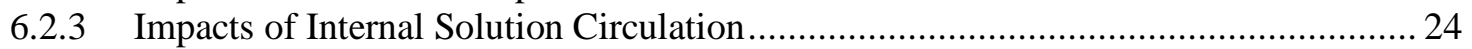

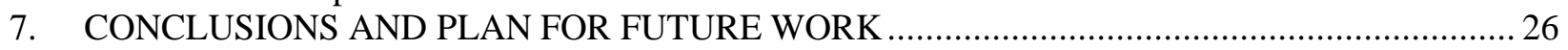

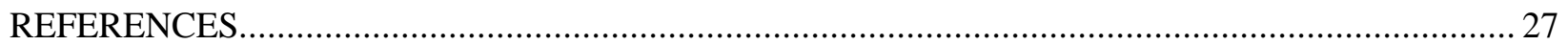




\section{LIST OF FIGURES}

Figure 1. A concept system design for utilizing the mobile sorption-based thermal battery (MSTB).....

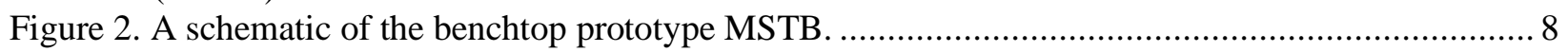

Figure 3. Specific energy $(\mathrm{kJ} / \mathrm{kg})$ of potential energy storage materials. ........................................ 8

Figure 4. A schematic of the experimental apparatus for characterizing crystallization and

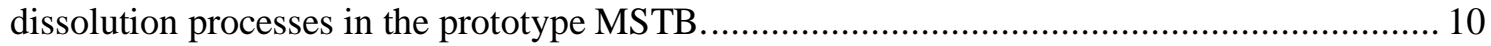

Figure 5. A photo showing the experimental apparatus built at ORNL. ............................................. 11

Figure 6. Photos showing an oven used for dehydrating the diluted $\mathrm{LiCl}$ solution (exterior on left,

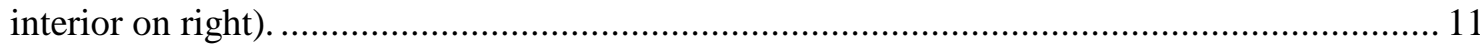

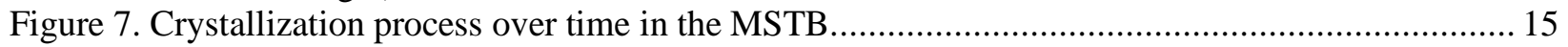

Figure 8. Measured data during crystallization process: (a) solution concentration; (b) temperature of solution and cooling water; (c) flow rate of solution; and (d) flow rate of cooling

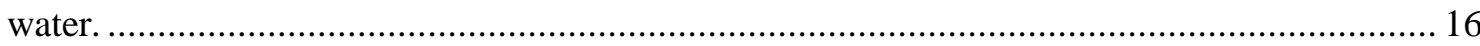

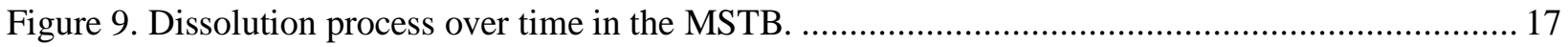

Figure 10. Measured data during dissolution process: (a) concentration of solution; (b)

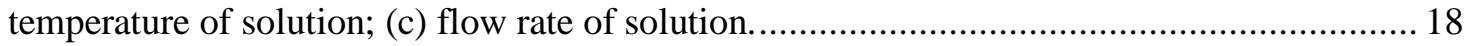

Figure 11. Calculated discharge rate of the MSTB based on dissolution test results............................ 19

Figure 12. Energy storage densities with different solution flow rates. ........................................... 20

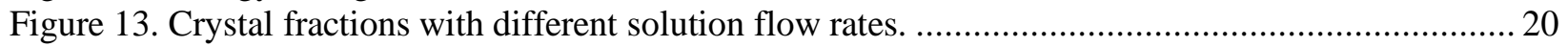

Figure 14. Crystal fraction resulting from various cooling water temperatures................................. 21

Figure 15. Energy storage densities resulting from various cooling water temperatures....................... 22

Figure 16. Comparison of energy storage densities between MSTB and other thermal storage

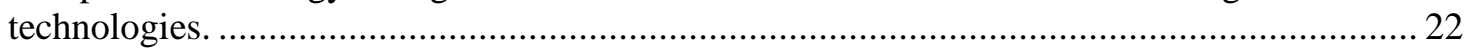

Figure 17. Discharge performance with different solution flow rates: (a) discharge rate over time; (b) maximum discharge rate. 23

Figure 18. Discharge performance with different inlet solution temperatures: (a) discharge rate over time; (b) maximum discharge rate.

Figure 19. Discharge performance with and without internal solution circulation: (a) discharge rate over time; (b) maximum discharge rate. 


\section{LIST OF TABLES}

Table 1. A comparison of technologies that use low-temperature geothermal energy for thermal applications

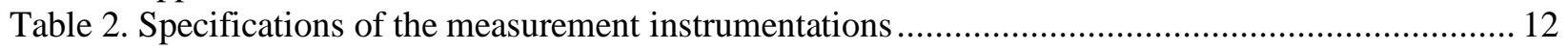

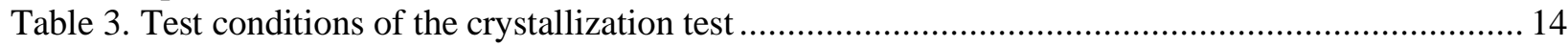

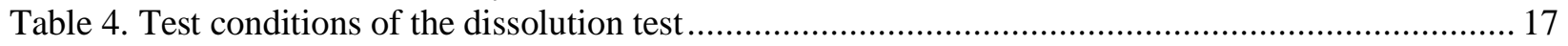

Table 5. Test conditions of crystallization with different solution flow rates...................................... 19

Table 6. Test conditions of crystallization with different cooling water temperatures............................. 21

Table 7. Dissolution test conditions with different solution flow rates ............................................. 23

Table 8. Dissolution test conditions with different inlet solution temperatures ................................... 24

Table 9. Dissolution test conditions of with/without internal solution circulation................................ 24 


\section{NOMENCLATURE}

$\begin{array}{ll}\text { Symbols } & \text { Description } \\ A & \text { increased mass in the MSTB } \\ B & \text { increased LiCl mass in the MSTB } \\ E_{S} & \text { stored energy in the MSTB } \\ F_{c} & \text { crystal fraction in the MSTB } \\ m & \text { mass flow rate } \\ M & \text { mass } \\ q_{v} & \text { latent heat of water vaporization } \\ Q_{d} & \text { discharge rate of the MSTB } \\ t & \text { time } \\ V & \text { volume } \\ X & \text { concentration }\end{array}$

Unit
$\mathrm{kg}$
$\mathrm{kg}$
$\mathrm{MJ}$
-
$\mathrm{g} / \mathrm{s}$
$\mathrm{kg}$
$\mathrm{kJ} / \mathrm{kg}$
$\mathrm{kW}$
$\mathrm{s}$
$\mathrm{m}^{3}$
-

\section{Greek letters}

$\rho$

density

$\mathrm{kg} / \mathrm{m}^{3}$

\section{Subscript \\ $c$ \\ $d$ \\ $e$ \\ $f$ \\ $i$ \\ in \\ in, $i$ \\ out \\ out, $f$ \\ S \\ solute \\ $s, d$ \\ $w$}

Abbreviations
ESD
LiBr
LiCl
MSTB
ORNL
PCM
TES

\section{Description}

crystal

after discharging process

equivalent

final time

initial time

inlet

inlet at initial time

outlet

outlet at final time

solid-liquid mixture

solute $(\mathrm{LiCl})$

diluted halide salt solution after discharging process

water

\section{Description}

energy storage density

lithium bromide

lithium chloride

mobile sorption-based thermal battery

Oak Ridge National Laboratory

phase change material

thermal energy storage 


\begin{abstract}
Around $20 \%$ of the total primary energy in the United States is consumed for thermal demands of buildings such as space cooling, dehumidification, and space heating (EIA 2018). Low-temperature geothermal energy is abundant and can effectively satisfy buildings' thermal demands. However, low-temperature geothermal energy is underutilized because the energy density of geothermal fluid is too low to justify the costs associated with transporting it between existing geothermal resources and buildings. The mobile sorption-based thermal battery (MSTB) system has been developed using three-phase (i.e., vapor-liquid, solution-solid, crystal) sorption technology to harvest low-temperature heat and store it with a much higher energy density than the geothermal fluid. The energy density of salt crystals is over six times higher than geothermal fluid, which makes long-distance transportation of salt crystals economically feasible. Salt crystals can be used to dehumidify air or provide space cooling in buildings, which alleviates peak demand on the electricity grid by offsetting electricity use for these end uses. This helps improve the grid's stability and resilience.
\end{abstract}

High-energy storage density, fast crystallization, and dissolution of salt crystals are all critical to the viability and performance of the MSTB system. Therefore, the design and operation of MSTB systems need to ensure effective generation and dissolution of salt crystals inside the MSTB. To achieve this target, this seedling project developed an experimental apparatus for characterizing the crystallization and dissolution processes. The energy density and potential latent cooling capacity of the MSTB are also evaluated based on lab test results.

The crystallization results showed that the generated lithium chloride hydrate crystals are fluffy, the crystallization process lasts about $50 \mathrm{~min}$, and the maximum crystal fraction (i.e., the ratio of crystal mass to the mass in the MSTB) can be up to $51.1 \%$ of the total mass in the MSTB at a solution flow rate of 1.58 $\mathrm{g} / \mathrm{s}$. The dissolution results show that the salt crystals in the MSTB can be fully dissolved within 15-28 min, based on different test conditions. Reducing solution flow rate and cooling water temperature can achieve increased energy storage density and crystal fraction. While the increase in the discharge rate (i.e., latent cooling capacity for dehumidifying air) is achieved by increasing flow rate and temperature of inlet diluted solution, as well as by using a pump for internal solution circulation, the discharge rate increases by $38 \%$, from $0.95 \mathrm{~kW}$ to $1.31 \mathrm{~kW}$. Compared with increasing the inlet solution flow rate, power consumption of salt solution transportation can be reduced by using a pump for internal solution circulation.

The crystallization test results also showed that the maximum energy storage density is $981.8 \mathrm{~kJ} / \mathrm{kg}$, and the maximum discharge rate of the dissolution tests is $1.79 \mathrm{~kW}$. Both are above the target values of 900 $\mathrm{kJ} / \mathrm{kg}$ and $1.75 \mathrm{~kW}$ for this project. The work reported here proves the feasibility and advancement of the MSTB system, which is helpful to the further study and improvement of the MSTB system. 


\section{INTRODUCTION}

Over $40 \%$ of the primary energy consumed in the United States is in buildings, and $40-70 \%$ of the energy consumed in buildings meets thermal demands, such as space cooling, space heating, and water heating. Low-temperature $\left(<150^{\circ} \mathrm{C}\right)$ geothermal energy is abundant and can be utilized either directly to provide space heating and water heating or through the absorption cooling technology to provide space cooling (DOE 2015). However, the existing thermal applications of the low-temperature geothermal energy are highly localized and relatively small in scale because the energy density of the geothermal fluid is too low to justify the cost of building a pipeline to transport geothermal fluid over long distances (OIT Geo-Heat Center 2005).

One possible solution to expand the utilization of the low-temperature geothermal energy is to store the geothermal heat in a medium with a sufficiently high energy storage density (ESD) so that it is economically feasible to transport the stored energy over long distances with existing means of transportation, such as tractor trailer trucks or freight trains. ESD is defined as the amount of energy that can be utilized at the demand side in each unit of volume or mass of the energy storage medium being transported between the energy resource and the thermal demand.

Conventional thermal energy storage (TES) technologies use either sensible heat of chilled or hot water (Nelson et al. 1999) or the latent heat of a phase change material (PCM) (Cabeza et al. 2011). The ESD of a TES technology using sensible heat depends on the temperature difference between the energy resource and the thermal demand. For storing heat in water with a temperature of $40-90^{\circ} \mathrm{C}$, the ESD is low (209 $\mathrm{kJ} / \mathrm{kg}$ ), and heavy insulation is needed to reduce heat loss to the environment during transportation. TES using latent heat of PCM offers higher ESD, but the ESD is usually lower than $350 \mathrm{~kJ} / \mathrm{kg}$ (i.e., the heat required for fusion of water). TES systems using PCM also need to be insulated to reduce heat loss during storage and transportation. N'Tsoukpoe et al. $(2013,2014)$ developed a lab-scale prototype for seasonal TES, which used concentrated salt solution to provide seasonal storage of solar heat with minimum loss.

A novel TES technology, mobile sorption-based thermal battery (MSTB), was invented at Oak Ridge National Laboratory (ORNL) by Liu et al. (2015) and Yang et al. (2016). The MSTB can be used as either a mobile device being transported back and forth between heat resources and thermal demands or as a stationary TES device, which is charged (storing energy) and discharged (releasing energy) at different times of the day or year. Figure 1 depicts a concept system design for using the MSTB to store geothermal energy and provide space cooling.

- At the geothermal site, the geothermal heat is used to drive off water from an aqueous salt solution to make it concentrated. The concentrated solution then flows into the MSTB, where it is cooled to allow salt in the concentrated solution to crystallize and form salt hydrate crystals, and the remaining solution becomes diluted. While salt crystals accumulate in the MSTB, the diluted solution circulates back into the regenerator to be concentrated. This process continues until the tank is filled with salt hydrate crystals (i.e., the MSTB is fully charged). Because salt crystals have a much higher salt concentration (e.g., the monohydrate of lithium chloride ( $\mathrm{LiCl}$ ) has a salt concentration of $70.2 \%$ ) than the saturated strong solution (e.g., $52 \%$ at $80^{\circ} \mathrm{C}$ ), ESD resulting from using salt hydrates could be two to three times higher than using liquid desiccant for energy storage. The fully charged MSTB can be transported to buildings or industrial plants to provide versatile thermal end uses such as cooling, heat pumping, and dehumidification.

- At the building site, the MSTB is connected to an absorption system to release the energy stored in crystals. The diluted solution leaving the absorption system flows into the MSTB. By dissolving the salt crystals stored in the MSTB, the diluted solution is re-concentrated and flows back to the absorption system to continue dehumidifying and/or providing space cooling to the 
building through an absorption-assisted evaporative cooling system without consuming any energy for regenerating the liquid desiccant. Once all the salt crystals in the MSTB are dissolved and the concentration of the remaining solution drops below a threshold (i.e., the MSTB is fully discharged), the MSTB is transported back to the geothermal site to be recharged for another cycle of operation.

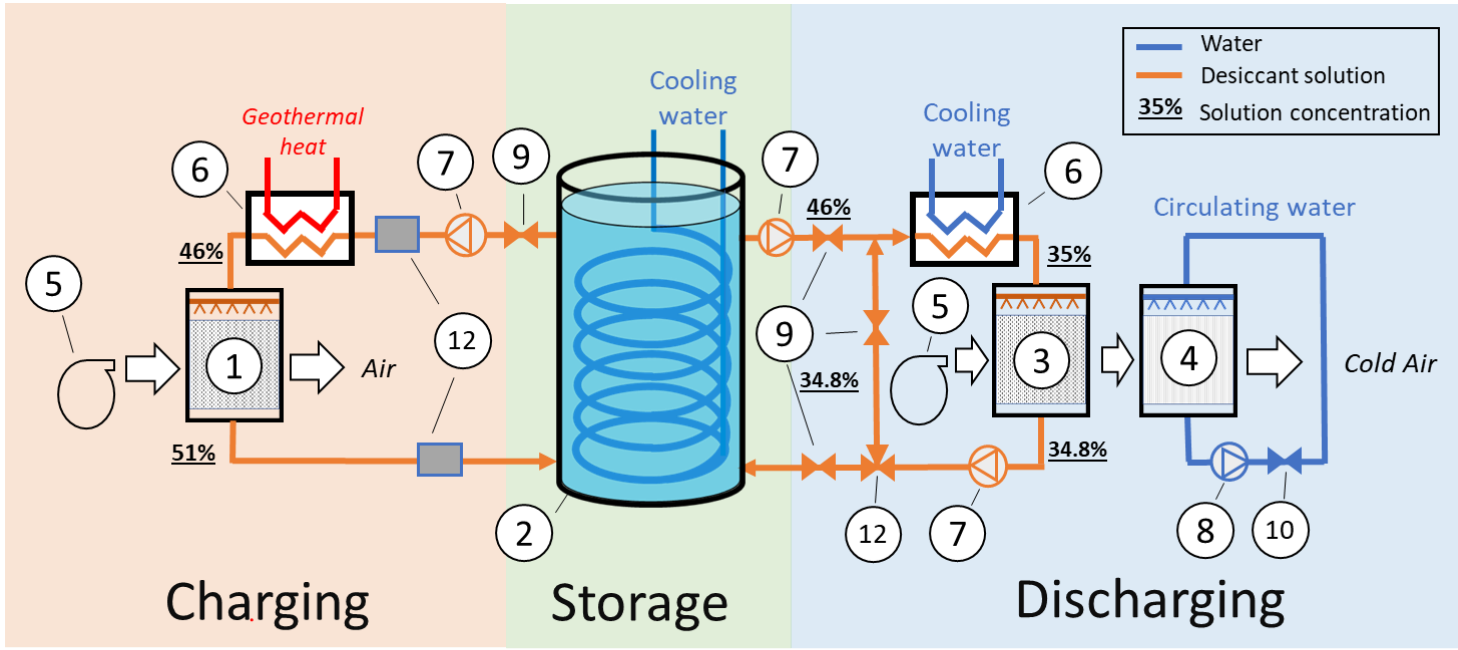

\section{1-regenerator; 2-MSTB; 3-dehumidifier; 4-evaporative cooler; 5-fan; 6-heat exchanger; 7-solution pump; 8-water pump; 9-solution valve; 10-water valve; 11-three-way valve; 12 -inline densimeter}

\section{Figure 1. A concept system design for utilizing the mobile sorption-based thermal battery (MSTB).}

Yang et al. compared existing and potential technologies for transporting low-temperature geothermal energy for thermal applications (Table 1). Their theoretical calculation results indicate that, among all the investigated technologies, the MSTB using lithium bromide can achieve the highest ESD $(915 \mathrm{~kJ} / \mathrm{kg}$ for space cooling), about 40 times higher than an absorption chiller driven by low-temperature geothermal heat. However, some significant technical challenges exist for applying this technology, including (1) dissolving crystals in time to increase the concentration of the weak solution at the building site and (2) preventing crystals from entering and/or forming in the absorber. Yang et al. recommended conducting an experimental study to characterize the process of crystal formation and dissolution, as well as building a prototype of the salt-crystal TES to verify its performance through laboratory and field tests.

Table 1. A comparison of technologies that use low-temperature geothermal energy for thermal applications

\begin{tabular}{|l|l|r|r|l|l|}
\hline \multirow{2}{*}{$\begin{array}{c}\text { Transported } \\
\text { medium }\end{array}$} & \multicolumn{1}{|c|}{$\begin{array}{c}\text { Application } \\
\text { technology }\end{array}$} & $\begin{array}{c}\text { Energy density } \\
\text { Heating } \\
{\left[\mathrm{kJ}_{\mathrm{th}} / \mathrm{kg}\right]}\end{array}$ & $\begin{array}{l}\text { Cooling } \\
{\left[\mathrm{kJ}_{\mathrm{clg}} / \mathrm{kg}\right]}\end{array}$ & Advantages & \multicolumn{1}{c|}{ Limitations } \\
\hline Water & Direct use & 146 & 23 & $\begin{array}{l}\text { Simplest } \\
\text { technology }\end{array}$ & Feasible only for a short distance \\
\hline Solid desiccant & Adsorption & 202 & 526 & $\begin{array}{l}\text { High-energy } \\
\text { density }\end{array}$ & $\begin{array}{l}\text { Needs high charging temperature, } \\
\text { slow charging/discharging, varying } \\
\text { outputs }\end{array}$ \\
\hline
\end{tabular}




\begin{tabular}{|l|l|l|l|l|l|}
\hline & $\begin{array}{l}\text { Two-step geothermal } \\
\text { absorption }\end{array}$ & - & 405 & $\begin{array}{l}\text { High-energy } \\
\text { density }\end{array}$ & $\begin{array}{l}\text { Technically challenging to maintain } \\
\text { vacuum at components and prevent air } \\
\text { infiltration, need to prevent } \\
\text { crystallization }\end{array}$ \\
\cline { 2 - 6 } $\begin{array}{l}\text { Salt } \\
\text { solution/crystal }\end{array}$ & MSTB* & - & 915 & $\begin{array}{l}\text { High-energy } \\
\text { density }\end{array}$ & $\begin{array}{l}\text { A new technology that needs to be } \\
\text { customized for geothermal } \\
\text { applications }\end{array}$ \\
\cline { 2 - 6 } & $\begin{array}{l}\text { Crystal enhanced } \\
\text { liquid desiccant } \\
\text { dehumidification }\end{array}$ & - & 857 & $\begin{array}{l}\text { High-energy } \\
\text { density, } \\
\text { ambient } \\
\text { pressure } \\
\text { operation }\end{array}$ & $\begin{array}{l}\text { Deals only with latent cooling load, } \\
\text { performance dependent on climate }\end{array}$ \\
\hline Ice & $\begin{array}{l}\text { Absorption } \\
\text { refrigeration (ice) }\end{array}$ & - & 355 & $\begin{array}{l}\text { Mature } \\
\text { technology }\end{array}$ & $\begin{array}{l}\text { Needs heavy insulation when } \\
\text { transporting ice in summer, varying } \\
\text { charge/discharge rate }\end{array}$ \\
\hline
\end{tabular}

* Originally named crystal-enhanced two-step geothermal absorption

The goal of this seedling project was to develop a benchtop prototype MSTB that has an energy density (medium only, without component) of $>900 \mathrm{~kJ} / \mathrm{kg}$ and a cooling capacity of $1.75 \mathrm{~kW}$. While other components shown in Figure 1 are commercially available, the MSTB is a unique innovation. Because both the salt crystal formation and dissolution processes take place in the MSTB, the design and operating conditions of MSTB are crucial to the cost and performance of the entire system shown in Figure 1.

A benchtop prototype MSTB has been developed and tested at ORNL to characterize the performance of the $\mathrm{LiCl}$ salt crystal formation and dissolution processes and to evaluate the ESD and latent cooling capacity of the prototype MSTB. This report summarizes the work performed from October 2018 to May 2019. In section 2, the development of the benchtop prototype MSTB is discussed. Section 3 presents a first-of-its-kind experimental apparatus for characterizing the formation and dissolution of salt crystals and for evaluating the performance of the MSTB. Performance metrics for the MSTB and associated evaluation methods are discussed in section 4. Lab test results for the benchtop prototype MSTB, including a parametric study of the impacts of several operating conditions on the MSTB's performance, are presented in section 5. Conclusions and recommendations for future work are provided in section 6.

\section{PROTOTYPE OF MOBILE SORPTION-BASED THERMAL BATTERY}

A benchtop prototype MSTB was designed and built at ORNL (Figure 2). The prototype MSTB comprises a cylindrical tank made of acrylic organic glass. The inner diameter of the tank is $15.2 \mathrm{~cm}$, the outer diameter is $16.5 \mathrm{~cm}$, and the height is $27.9 \mathrm{~cm}$. A helical coil made with stainless steel is inserted in the tank's center. Fine-mesh plastic filters are applied at the top and bottom of the tank. There is an air vent at the top of the tank. Two $0.6 \mathrm{~cm}$ (inner) diameter openings are found on each side of the tank. The two openings at the bottom are below the filter at the bottom, and the two openings at the top are above the filter. This design is intended to prevent salt crystals from escaping from the tank. The solution flows from the opening in the bottom and exits from the opening at the other side of the tank. The other remaining openings are used for circulating solution inside the tank. A grid of thermocouples is installed in the tank to measure the temperature distribution of solutions/crystals inside the tank. 


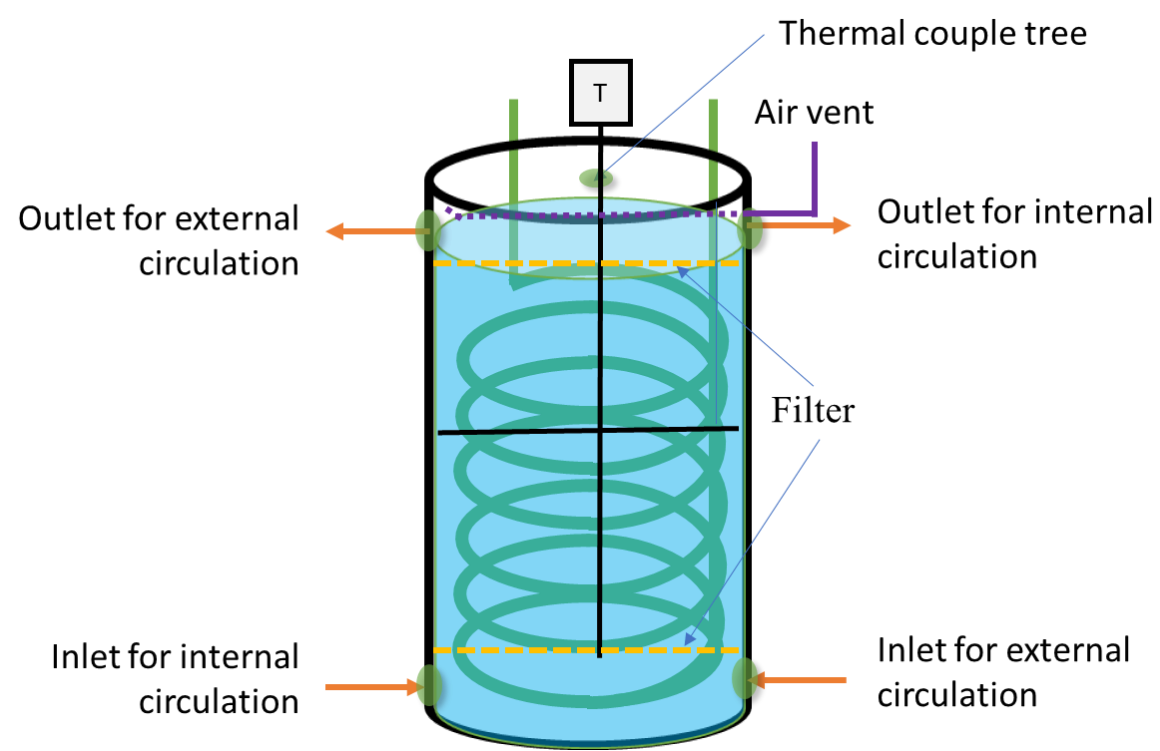

Figure 2. A schematic of the benchtop prototype MSTB.

The maximum ESD (i.e., specific energy) of an MSTB is determined by the selection of the energy storage medium and thermal applications where the stored energy is used. Figure 3 compares the calculated MSTB's maximum ESDs using various energy storage mediums and for different thermal applications. As can be seen, storing heat by making $\mathrm{LiCl}$ hydrate crystals and releasing the stored latent heat for air dehumidification results in the highest ESD among all the investigated scenarios.

Furthermore, the $\mathrm{LiCl}$ solution can be generated at a relatively low temperature $\left(75^{\circ} \mathrm{C}\right)$, which indicates a good fit for utilizing low-temperature geothermal energy.

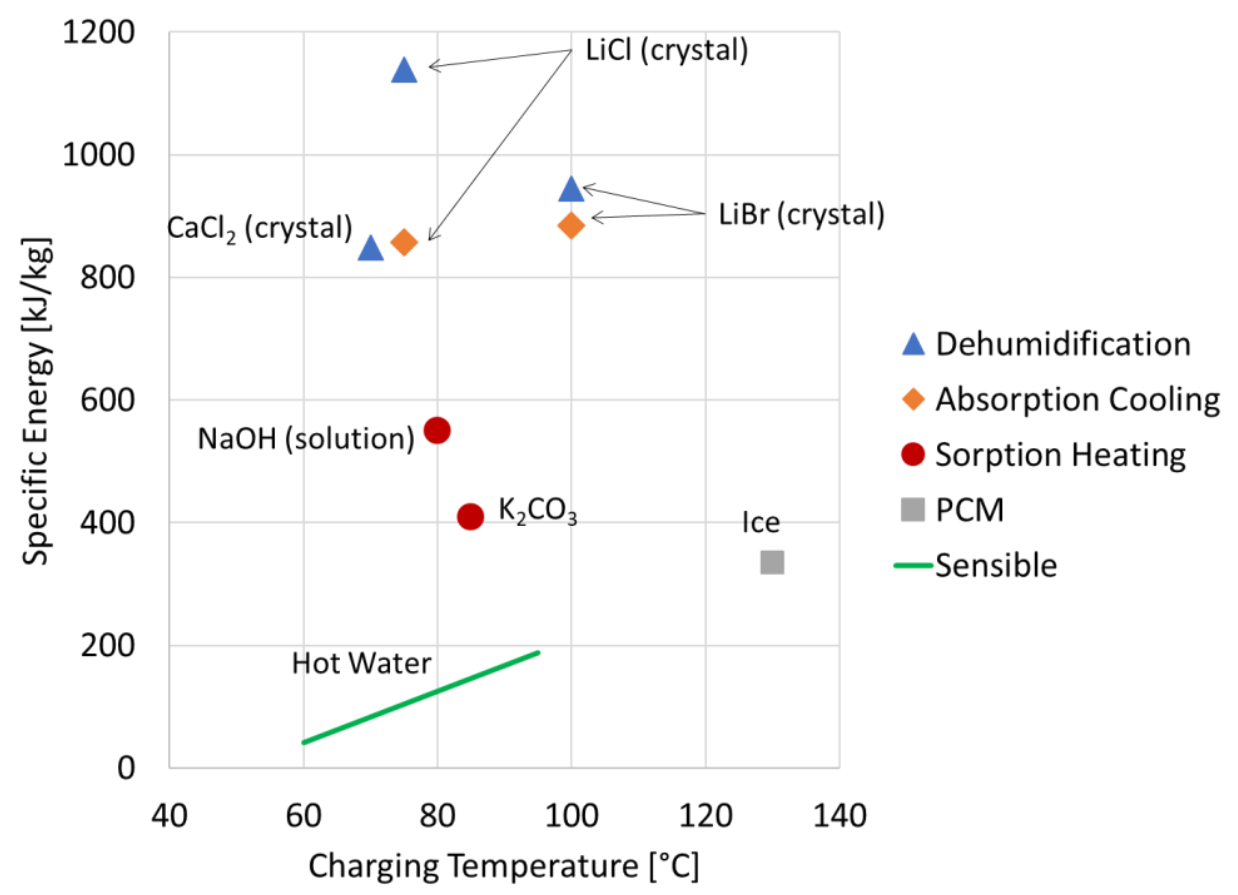

Figure 3. Specific energy $(\mathrm{kJ} / \mathrm{kg})$ of potential energy storage materials. 
The ESDs shown in figure 3 are calculated based on the latent heat stored in the MSTB and the mass of an MSTB after the stored latent heat is fully utilized. The latent heat stored in halide salts (i.e., $\mathrm{LiCl}, \mathrm{LiBr}$, and $\mathrm{CaCl}_{2}$ ) is calculated based on the difference in the concentration between the salt hydrates and the diluted salt solution after being used for thermal applications. For dehumidification applications, it is assumed that the diluted salt solution is at $30^{\circ} \mathrm{C}$ and has an equilibrium water vapor pressure equal to that of saturated air at $7^{\circ} \mathrm{C}$. For cooling applications, it is assumed that the diluted salt solution is at $30^{\circ} \mathrm{C}$ and has an equilibrium water vapor pressure equal to that of saturated air at $5^{\circ} \mathrm{C}$.

The ESDs resulting from using halide salts are higher than that of the conventional TES system using hot water or ice and other sorption-based TES systems. $\mathrm{NaOH}$ solution was used in the European Union (EU) COMTES project (Fumey et al. 2014; Köll et al. 2015) for solar heat storage. When charged at $\sim 80^{\circ} \mathrm{C}$ and discharged at $\sim 60^{\circ} \mathrm{C}, \mathrm{NaOH}$ solution can provide specific energy of $550 \mathrm{~kJ} / \mathrm{kg}$. However, $\mathrm{NaOH}$ solution is highly caustic, especially at high temperatures, requiring careful handling and special containers (Weber and Dorer 2008), which also makes it unsuitable for transportation. $\mathrm{K}_{2} \mathrm{CO}_{3}$ adsorption was used in the European Union CREATE project (Helden et al. 2015; Sögütoglu et al. 2018) to provide solar heat storage and high theoretical specific energy. However, the material was found to undergo significant volume expansion when it absorbed water and released heat; thus it must be arranged loosely to avoid agglomeration, which reduces its volumetric energy density.

\section{EXPERIMENTAL APPARATUS FOR CHARACTERIZING MSTB}

The ESD of an MSTB depends on how many salt crystals can be produced in it, and the latent cooling capacity (i.e., discharge rate) that can be maintained by an MSTB is determined by how quick the salt crystals in the tank can be dissolved. To characterize the formation and dissolution processes of hydrate crystals in an MSTB, a first-of-its-kind experimental apparatus was designed and built at ORNL.

\subsection{EXPERIMENTAL APPARATUS AND TEST PROCEDURE}

The experimental apparatus was designed to test the performance of the prototype MSTB for both making and dissolving salt crystals. Figure 4 shows the schematic of the experimental apparatus, and Figure 5 is a photo of the experimental apparatus built at ORNL. The experimental apparatus comprises the prototype MSTB (with 5 L capacity), two identical solution tanks (with $10 \mathrm{~L}$ capacity for each), two piping systems (with an identical circulation pump and control valves), and two refrigerated circulating water baths. $\mathrm{LiCl}$ aqueous solution was adopted in this project as the energy storage medium. Because $\mathrm{LiCl}$ is corrosive to some metals, all the components in the experimental apparatus were made of plastic that can endure temperatures of up to $95^{\circ} \mathrm{C}$.

The experimental apparatus can test the crystallization and dissolution process separately at adjustable operating conditions, including the flow rate, concentration, and temperature of the LiCl solution feeding into the MSTB. The temperatures of the solution in each of the two holding tanks can be maintained by the water bath though a helical heat exchanger immersed in the tank. Another water bath is used to provide a constant inlet cooling water temperature to the heat exchanger in the MSTB. Mass flow rates of the $\mathrm{LiCl}$ solutions entering and leaving the MSTB are manually adjusted with a needle valve in each of the piping systems to keep the mass of the MSTB nearly constant during a test.

At the beginning of a crystallization test, both the MSTB and a holding tank are filled with the hot and concentrated $\mathrm{LiCl}$ solution. Cooling water at a temperature lower than the saturated temperature of the concentration $\mathrm{LiCl}$ solution is then circulated through the heat exchanger in the MSTB, and the hot and concentrated $\mathrm{LiCl}$ solution in the holding tank is pumped into the MSTB continuously through the piping 
system attached to the holding tank. The concentrated solution in the MSTB is cooled by the cooling water and crystallized on the heat exchanger surface. As salt crystals are generated, the remaining liquid solution in the MSTB becomes dilute and is pumped to another holding tank. The test continues until the concentration of the leaving solution does not change (i.e., no more solution crystalizes in the MSTB).

The dissolution test is performed after the MSTB is saturated with salt crystals. To test the dissolution process, warm and diluted solution from a holding tank is pumped into the MSTB, where it dissolves the salt crystals and the salt concentration of the liquid solution in the MSTB increases. The concentrated solution is pumped out from the MSTB into the other solution tank.

The diluted solution is put in a drying oven (Figure 6), which is maintained at $80^{\circ} \mathrm{C}$, to be re-concentrated for the next crystallization test. To prevent unwanted crystallization in the piping system and circulation pumps, a water flushing system is added, as shown in Figure 4. When a test is finished, tap water is used to flush the piping system and the pumps until the reading of the densimeter in each piping system decreases to $1 \mathrm{~g} / \mathrm{cm}^{3}$.

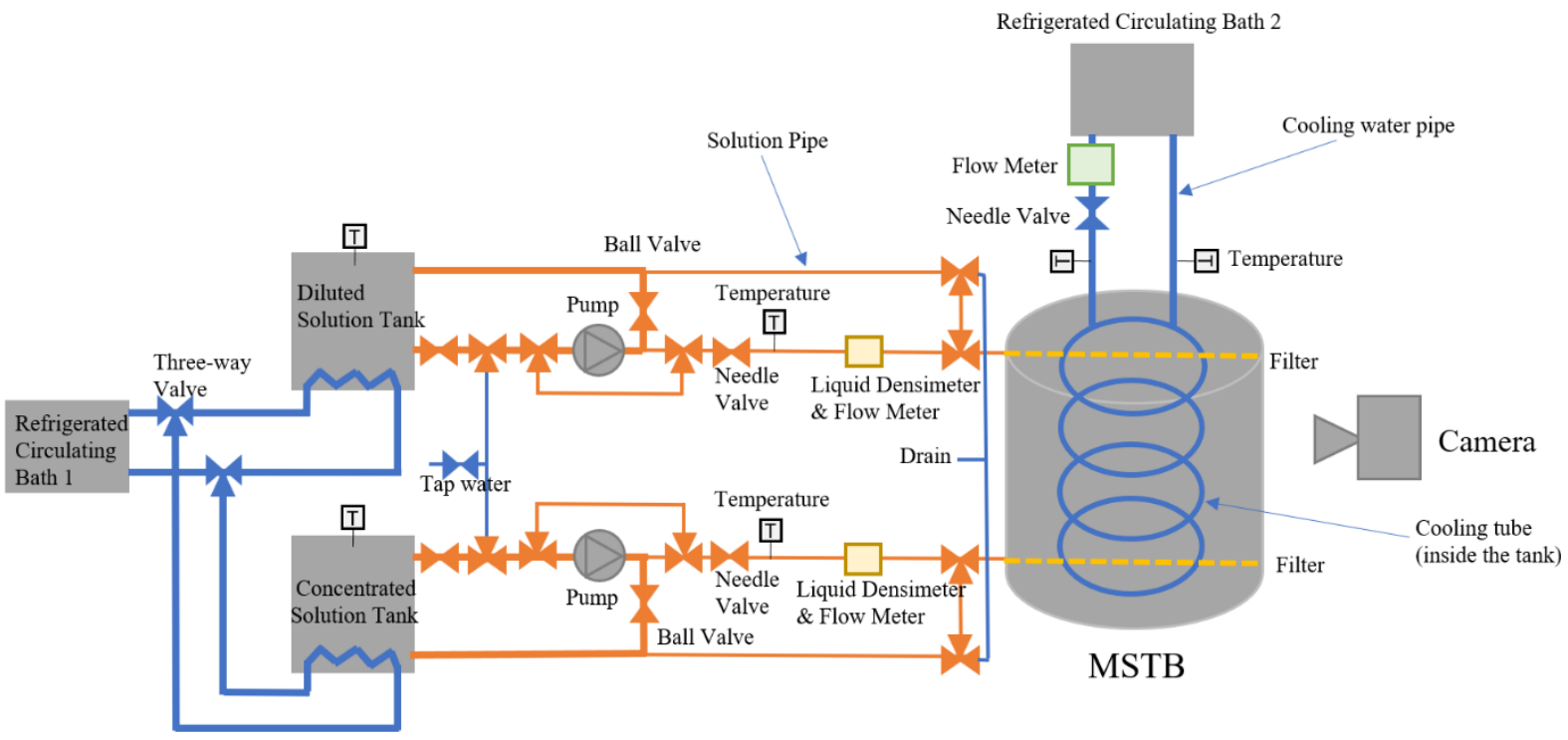

Figure 4. A schematic of the experimental apparatus for characterizing crystallization and dissolution processes in the prototype MSTB. 


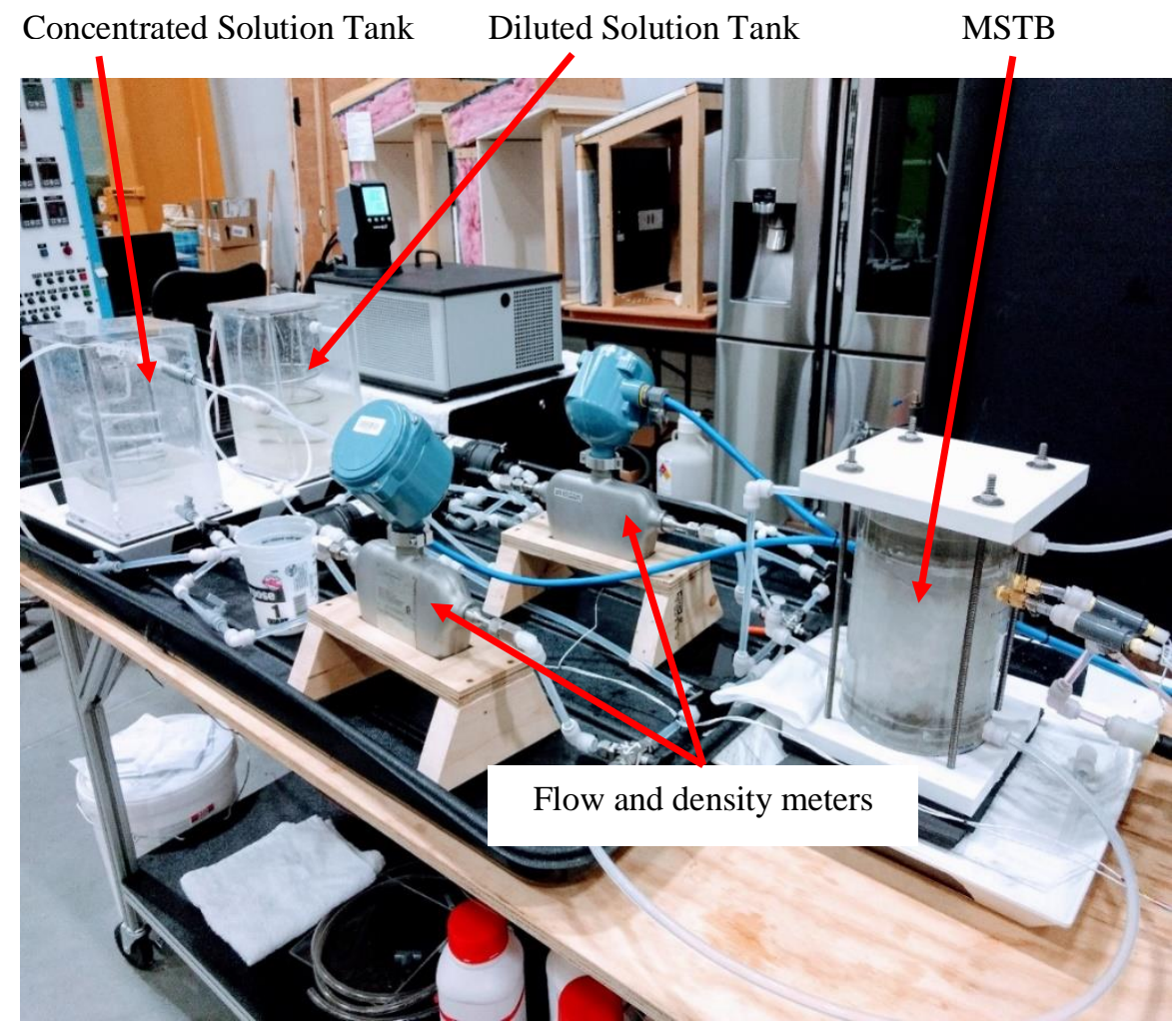

Figure 5. A photo showing the experimental apparatus built at ORNL.
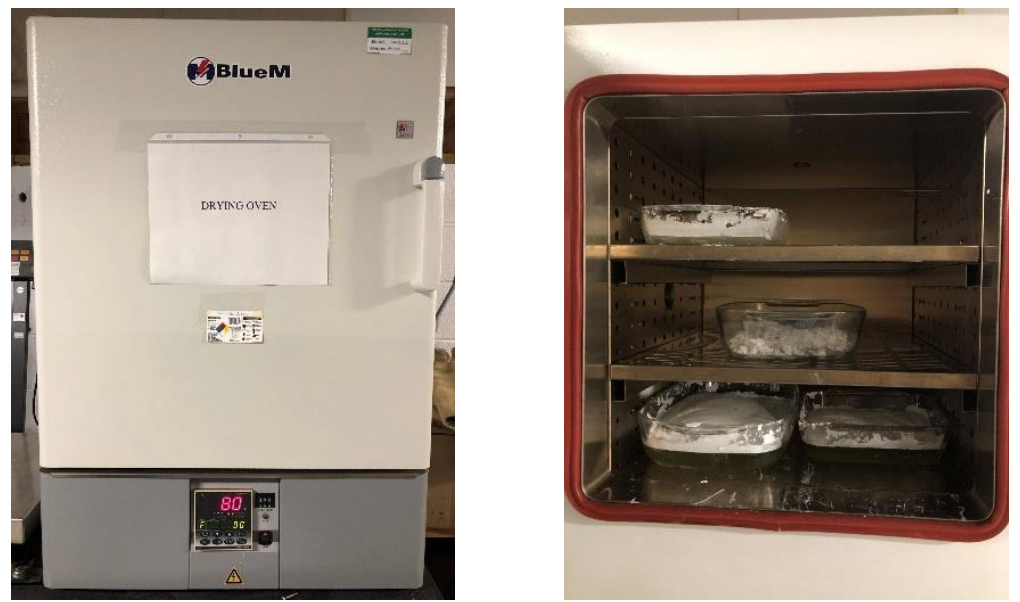

Figure 6. Photos showing an oven used for dehydrating the diluted $\mathrm{LiCl}$ solution (exterior on left, interior on right).

\subsection{MEASUREMENTS AND DATA ACQUISITION}

The measurements and data collection points are identified in Figure 4. The inlet and outlet temperatures of the salt solution and the cooling water in the MSTB are measured with four-wire resistance temperature detectors. The temperature of the solution in each of the two holding tanks is measured with a T-type thermocouple. The flow rate of cooling water is measured with an electromagnetic flowmeter 
(0.1-10 gallons per minute, $\pm 0.5 \%)$. Flow rate and density of the solution going through each of the two piping systems are measured with a Micro Motion Coriolis flow and density meter. A camera is used to visually record the crystallization/dissolution process. Table 2 lists the specifications of the measurement instruments. All the measured data are recorded at $5 \mathrm{~s}$. intervals with a Campbell Scientific data acquisition system.

Table 2. Specifications of the measurement instrumentations

\begin{tabular}{|c|c|c|c|}
\hline Measured value & Instrument & Range & Uncertainty \\
\hline $\begin{array}{l}\text { Temperature of salt } \\
\text { solution and cooling } \\
\text { water }\end{array}$ & $\begin{array}{l}\text { RTD [Omega PR-20 } \\
\text { SERIES, Class “A” DIN] }\end{array}$ & $\begin{array}{c}-50-260^{\circ} \mathrm{C} \\
\text { (instrument range) }\end{array}$ & $\pm 0.15^{\circ} \mathrm{C}$ \\
\hline $\begin{array}{l}\text { Temperature of solution } \\
\text { in the tanks }\end{array}$ & $\begin{array}{l}\text { T-type thermocouple probes } \\
\text { [Omega] }\end{array}$ & $-270-370^{\circ} \mathrm{C}$ & $\pm 0.5^{\circ} \mathrm{C}$ \\
\hline $\begin{array}{l}\text { Flow rate of cooling } \\
\text { water }\end{array}$ & $\begin{array}{l}\text { Electromagnetic flow meter } \\
\text { [QSE05NPT09] }\end{array}$ & $\begin{array}{l}0.1-10 \text { GPM (instrument } \\
\text { range) }\end{array}$ & $\pm 0.5 \%$ of rate \\
\hline Flow rate of solution & $\begin{array}{l}\text { MicoMotion ELITE } \\
\text { CMFS010H Coriolis }\end{array}$ & $0-110 \mathrm{~L} / \mathrm{h}$ & $\pm 0.05 \%$ of rate \\
\hline Density of solution & $\begin{array}{l}\text { MicroMotion ELITE } \\
\text { CMFS010H Coriolis }\end{array}$ & $0-4000 \mathrm{~kg} / \mathrm{m}^{3}$ & $\pm 0.2 \mathrm{~kg} / \mathrm{m} 3$ \\
\hline
\end{tabular}

DIN: [Deutsche Institut für Normung]; GPM: gallons per minute; RTD: resistance temperature detector

\section{PERFORMANCE METRICS AND EVALUATION METHODS}

The MSTB's performance can be evaluated with two indicators: the ESD and the discharge rate, $Q_{\mathrm{d}}$. ESD is a performance index of the MSTB, while $Q_{\mathrm{d}}$ depends not only on MSTB but also on the associated discharging systems.

ESD is calculated with Eq. (1):

$$
E S D=\frac{M_{w} q_{v}}{M_{s, d}}
$$

where $M_{s, d}$ is the mass of diluted halide salt solution after the discharging process $(\mathrm{kg}), M_{w}$ is the mass of water released from the diluted solution after the charging process $(\mathrm{kg})$, and $q_{v}$ is the latent heat of vaporization per unit mass of water $(\mathrm{kJ} / \mathrm{kg})$.

The mass balance equation of the water release process is shown as Eq. (2):

$$
\left(M_{s, d}-M_{w}\right)\left(1-X_{e}\right)+M_{w}=M_{s, d}\left(1-X_{d}\right),
$$

where $X_{e}$ is the equivalent solution concentration after the charging process (-), $X_{d}$ is the solution concentration after the discharging process, and the value of $X_{d}$ in a typical liquid desiccant dehumidifier is 0.35 .

If you combine Eqs. (1) and (2), ESD can be calculated with Eq. (3):

$$
E S D=\frac{X_{e}-X_{d}}{X_{e}} q_{v}
$$

The equivalent solution concentration $\left(X_{e}\right)$ is calculated by Eq. (4): 


$$
X_{e}=\frac{M_{\text {solute }}}{M_{s}}=\frac{M_{c} X_{c}+\left(V_{f}-M_{c} / \rho_{c}\right) \rho_{f} X_{f}}{\left(V_{f}-M_{c} / \rho_{c}\right) \rho_{f}+M_{c}}
$$

where $M_{\text {solute }}, M_{s}, M_{c}, X_{c}$, and $\rho_{c}$ are the total mass of solute $(\mathrm{kg})$, the total mass of solid-liquid mixture $(\mathrm{kg})$, the total mass $(\mathrm{kg})$, and the equivalent concentration (-) and density $\left(\mathrm{kg} / \mathrm{m}^{3}\right)$ of salt crystals generated in the MSTB, respectively. Where the crystal might be monohydrate or dihydrate depending on the cooling temperature (Conde 2004), $V_{f}$ is the final total volume $\left(\mathrm{m}^{3}\right)$ of the solid-liquid mixture in the MSTB and $X_{f}$ and $\rho_{f}$ are the final concentration (-) and density $\left(\mathrm{kg} / \mathrm{m}^{3}\right)$ of the remaining solution in the MSTB, respectively.

The calculation of the total mass of salt crystals $\left(M_{c}\right)$ is as follows. The mass balance in the MSTB during the crystallization process is shown in Eq. (5):

$$
\int_{t_{i}}^{t_{f}}\left(m_{\text {in }}-m_{\text {out }}\right) d t=\left(V_{f}-\frac{M_{c}}{\rho_{c}}\right) \rho_{f}+M_{c}-V_{i} \rho_{i}
$$

where $t_{i}$ and $t_{f}$ represent the initial and final time (s), respectively; $m_{\text {in }}$ and $m_{\text {out }}$ represent the mass flow rate of inlet solution and outlet solution $(\mathrm{kg} / \mathrm{s})$, respectively; and $V_{i}$ and $\rho_{i}$ represent the volume $\left(\mathrm{m}^{3}\right)$ and density of solution $\left(\mathrm{kg} / \mathrm{m}^{3}\right)$ in the MSTB at the initial time, respectively.

The mass balance of halide salt in the MSTB during the crystallization process is shown in Eq. (6):

$$
\int_{t_{i}}^{t_{f}}\left(m_{\text {in }} X_{\text {in }}-m_{\text {out }} X_{\text {out }}\right) d t=M_{c} X_{c}+\left(V_{f}-\frac{M_{c}}{\rho_{c}}\right) \rho_{f} X_{f}-V_{i} \rho_{i} X_{i}
$$

where $X_{\text {in }}, X_{\text {out }}$, and $X_{i}$ represent the concentration (-) of inlet solution and outlet solution and solution in the MSTB at the initial time, respectively.

Let

$$
\begin{gathered}
A=\int_{t_{i}}^{t_{f}}\left(m_{\text {in }}-m_{\text {out }}\right) d t \\
B=\int_{t_{i}}^{t_{f}}\left(m_{\text {in }} X_{\text {in }}-m_{\text {out }} X_{\text {out }}\right) d t .
\end{gathered}
$$

Assuming that (1) the solution in MSTB is well mixed, so the state of the outlet solution is the same as the solution in the MSTB and (2) the volume of the solid-liquid mixture in the MSTB does not change, the following equations can be obtained.

$$
\begin{gathered}
X_{i}=X_{i n, i}, \rho_{i}=\rho_{\text {in }, i} \\
X_{f}=X_{\text {out }, f}, \rho_{f}=\rho_{\text {out }, f} \\
V_{i}=V_{f}=V,
\end{gathered}
$$

where subscripts $i$ and $f$ represent the initial and final states of the solution in the MSTB, respectively, and subscripts in, $i$ and $o u t, f$ represent the initial state of inlet solution and final state of outlet solution, respectively.

Based on Eqs. (9), (10), and (11), Eq. (4) can be converted to Eq. (12): 


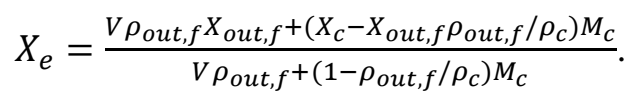

Combining Eqs. (5), (6), (7), and (8) together with Eqs. (9), (10), and (11), the total mass of salt crystals $\left(M_{c}\right)$ can be calculated with Eq. (13):

$$
M_{C}=\frac{\left(\rho_{\text {out }, f} X_{\text {out }, f}-\rho_{\text {in }, i} X_{\text {in }, i}\right) A-\left(\rho_{\text {out }, f}-\rho_{\text {in }, i}\right) B}{\left(\rho_{\text {out }, f}-\rho_{\text {in }, i}\right)\left(\frac{X_{\text {out }, f} \rho_{\text {out }, f}}{\rho_{c}}-X_{C}\right)+\left(\rho_{\text {out }, f} X_{\text {out }, f}-\rho_{\text {in }, i} X_{\text {in }, i}\right)\left(1-\frac{\rho_{\text {out }, f}}{\rho_{c}}\right)} .
$$

A and B can be calculated with the solution's measured density and flow rate. Combining Eqs. (3), (12), and (13), the ESD can finally be calculated.

The crystal fraction (i.e., the ratio of crystal mass to the mass in the MSTB) $\left(F_{c}\right)$ in the MSTB after the crystallization process is calculated by Eq. (14):

$$
F_{c}=\frac{M_{c}}{\rho_{i} V_{i}+A}=\frac{M_{c}}{\rho_{i n, i} V+A} .
$$

The stored energy $\left(E_{\mathrm{s}}\right)$ in the MSTB is calculated by Eq. (15):

$$
E_{s}=M_{w} q_{v}=\left(M_{s, d}-M_{s}\right) q_{v}=\left(\frac{X_{e}}{X_{d}}-1\right)\left(\rho_{i n, i} V+A\right) q_{v} .
$$

The MSTB's discharge rate $\left(Q_{\mathrm{d}}\right)$ is used to evaluate the dissolution performance when the discharging system uses the liquid desiccant solution dissolved from the MSTB. $Q_{\mathrm{d}}$ is the latent cooling capacity for dehumidifying air and can be calculated by Eq. (16):

$$
Q_{d}=\left(\frac{m_{o u t} X_{o u t}}{X_{d}}-m_{o u t}\right) q_{v} .
$$

\section{EXPERIMENTAL RESULTS AND DISCUSSIONS}

\subsection{CRYSTALLIZATION TEST RESULTS}

The crystallization test was conducted in the MSTB under test conditions shown in Table 3. The inlet parameters listed on the table are the average values for the measured data. The strong solution with a concentration of $50.3 \%$ and a flow rate of $2.04 \mathrm{~g} / \mathrm{s}$ flowed into the MSTB, where it was cooled with $20.4^{\circ} \mathrm{C}$ cooling water through a helical heat exchanger immersed in the MSTB to make salt crystals. Meanwhile, the diluted solution in the tank resulting from the crystallization flowed out of the tank with the same mass flow rate as the influent of the strong solution.

Table 3. Test conditions of the crystallization test

\begin{tabular}{|c|c|c|c|c|c|}
\hline $\begin{array}{c}\text { Mass flow rate } \\
\text { of inlet solution } \\
(\mathrm{g} / \mathrm{s})\end{array}$ & $\begin{array}{c}\text { Concentration } \\
\text { of inlet solution } \\
(\%)\end{array}$ & $\begin{array}{c}\text { Temperature of } \\
\text { inlet solution } \\
\left({ }^{\circ} \mathrm{C}\right)\end{array}$ & $\begin{array}{c}\text { Flow rate of } \\
\text { cooling water } \\
(\mathrm{L} / \mathrm{min})\end{array}$ & $\begin{array}{c}\text { Inlet } \\
\text { temperature of } \\
\text { cooling water } \\
\left({ }^{\circ} \mathrm{C}\right)\end{array}$ & $\begin{array}{c}\text { Outlet } \\
\text { temperature of } \\
\text { cooling water } \\
\left({ }^{\circ} \mathrm{C}\right)\end{array}$ \\
\hline 2.04 & 50.3 & 64.0 & 0.90 & 20.4 & 21.8 \\
\hline
\end{tabular}


Figure 7 shows the evolution of crystals over time during the crystallization test. It can be seen that the $\mathrm{LiCl}$ hydrate crystals were generated first on the surface of the cooling coil and the tank wall, as the temperature at these places was lower, and then the crystals accumulated in the tank. The crystals were fluffy, which is helpful for dissolution. More than half of the tank was occupied by the crystals within 30 min, and the tank was almost full of crystals after $40 \mathrm{~min}$. The data measured during the crystallization test are shown in Figure 8. In this test, the inlet conditions of the $\mathrm{LiCl}$ solution and the cooling water were maintained as their initial settings. It can be found from Figure 8a that the concentration of the solution leaving the MSTB was the same as the inlet solution concentration at the beginning, and then it dropped to $\sim 1.5 \%$ lower than that of the inlet solution. This indicated the crystals were forming, resulting in dilution of the remaining solution in the MSTB.

Based on test results and the calculation method described in section 3, the crystallization performance was evaluated as shown below:

- The total mass of salt crystals $\left(M_{c}\right)$ generated in the MSTB was $2.065 \mathrm{~kg}$, and the mass percentage of the crystals in the MSTB was $34.4 \%$.

- $\quad$ The ESD was $903.0 \mathrm{~kJ} / \mathrm{kg}$.

ESD can be increased by generating more salt crystals. Proposed methods for achieving this goal include changing the flow rate of solution and cooling water temperature, which will be discussed in section 6 .
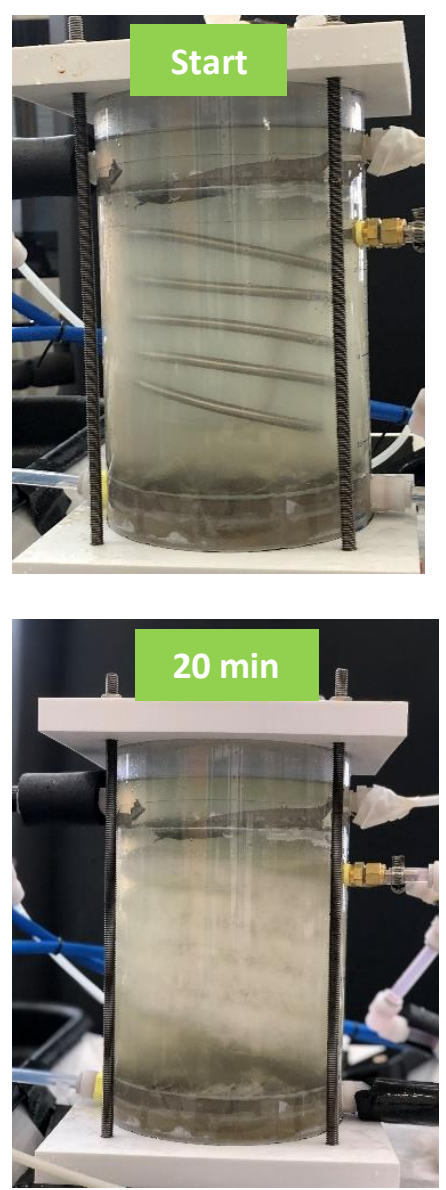
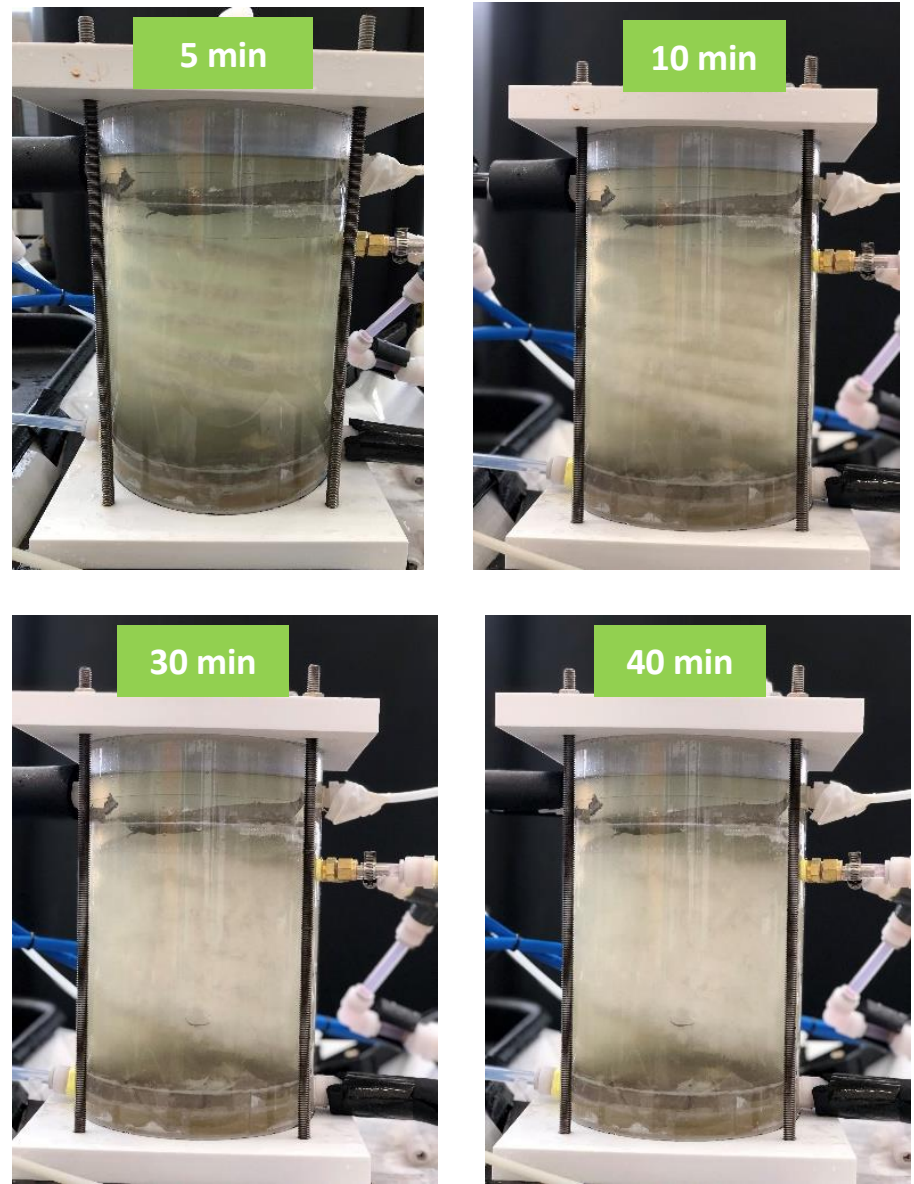

Figure 7. Crystallization process over time in the MSTB. 

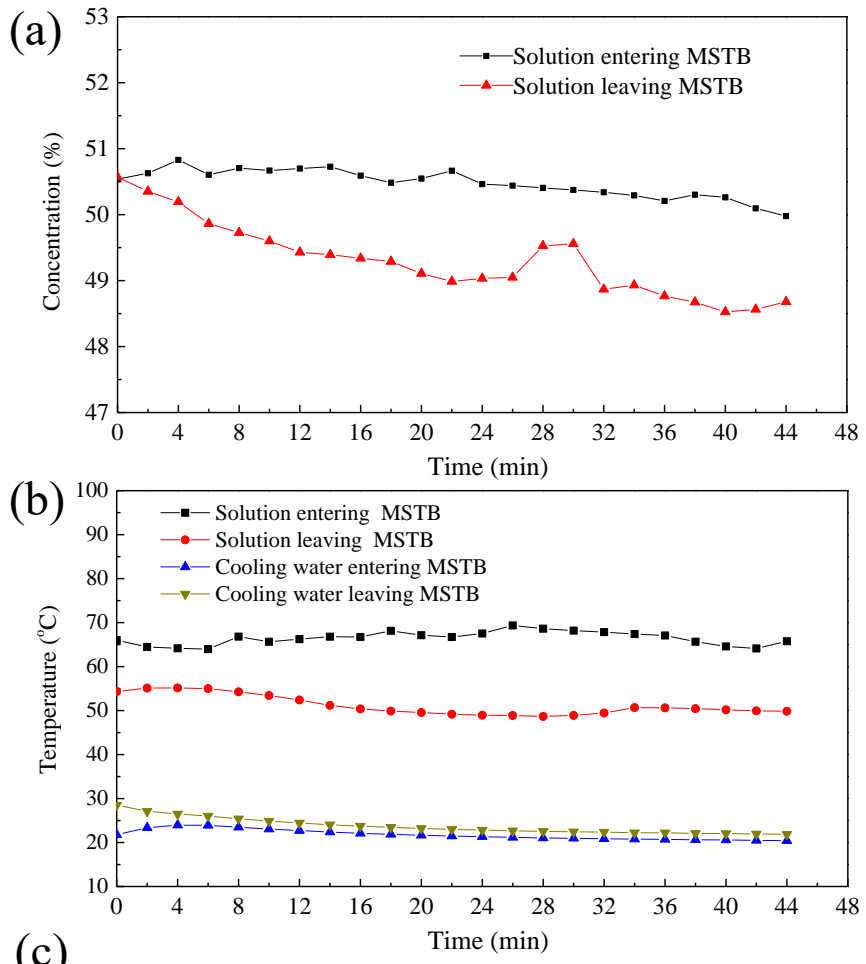

(c)

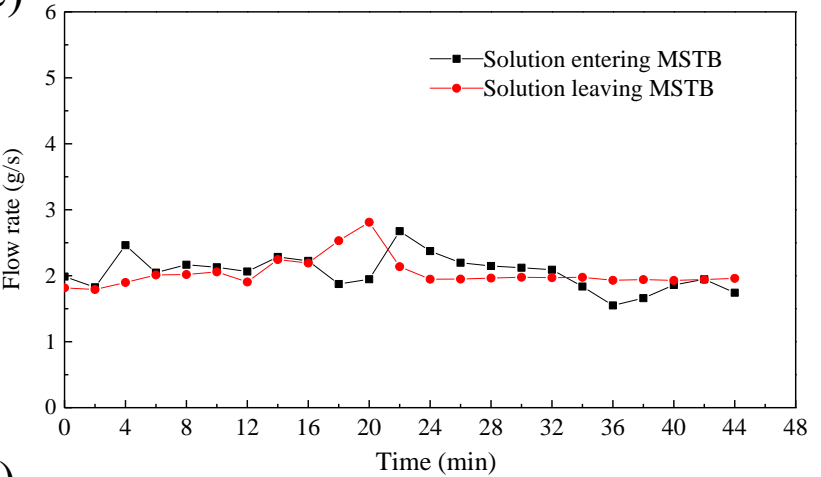

(d)

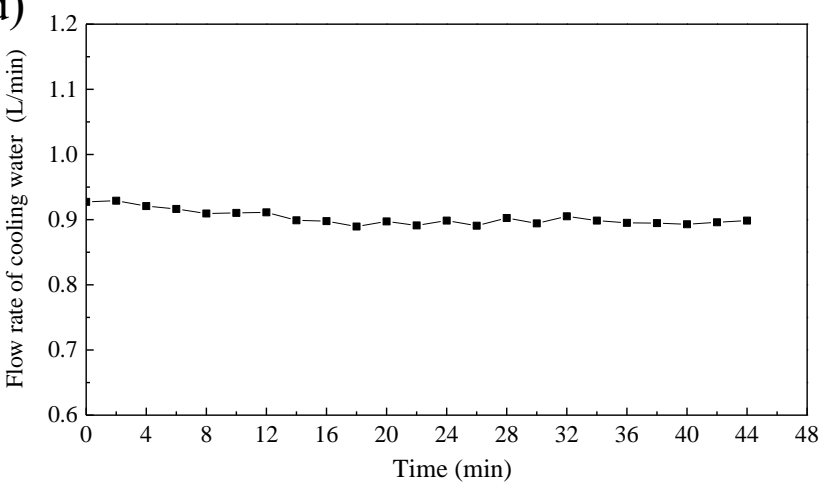

Figure 8. Measured data during crystallization process: (a) solution concentration; (b) temperature of solution and cooling water; (c) flow rate of solution; and (d) flow rate of cooling water. 


\subsection{DISSOLUTION TEST RESULTS}

The dissolution test was also conducted in the MSTB. The test condition is shown in Table 4. In this test, a $\mathrm{LiCl}$ solution with a concentration of $35.1 \%$ and a temperature of $40.9{ }^{\circ} \mathrm{C}$ flowed into the MSTB for dissolving the crystals in the tank. Meanwhile, the concentrated solution resulting from dissolving crystals flowed out of the MSTB. The inlet condition of the solution was kept constant to mimic the typical leaving condition of a $\mathrm{LiCl}$ solution after dehumidifying the air to a humidity ratio of $6-7 \mathrm{~kg} / \mathrm{kg}$. The inlet and outlet flow rates of the solution were maintained at about $5.9 \mathrm{~g} / \mathrm{s}$.

Table 4. Test conditions of the dissolution test

\begin{tabular}{|c|c|c|}
\hline $\begin{array}{c}\text { Mass flow rate of inlet solution } \\
(\mathrm{g} / \mathrm{s})\end{array}$ & $\begin{array}{c}\text { Concentration of inlet solution }(\%) \\
\text { Temperature of inlet solution }\left({ }^{\circ} \mathrm{C}\right)\end{array}$ \\
\hline 5.90 & 35.1 & 40.9 \\
\hline
\end{tabular}

The dissolution process over time is shown in Figure 9. It can be seen that the LiCl hydrate crystals were dissolved very fast. More than half of crystals were dissolved in $8 \mathrm{~min}$, and almost all of them were dissolved in $16 \mathrm{~min}$. The measured data during the dissolution test are shown in Figure 10. It can be seen from Figure 10a that the concentration of the solution leaving the MSTB is about 12 percentage points higher than that of inlet solution at the beginning and the difference gradually reduced to 5 percentage points in less than $20 \mathrm{~min}$. These results indicate that the crystals were dissolved quickly to increase the concentration of the solution entering the MSTB.

The discharge rate of the MSTB over time was calculated based on test results and the calculation method described in section 3. The calculated result is shown in Figure 11. It shows that the prototype MSTB maintained a discharge rate of above $1 \mathrm{~kW}$ during the dissolution process, and the maximum discharge rate was as high as $1.3 \mathrm{~kW}$. To further improve the discharge rate for reaching the $1.75 \mathrm{~kW}$ goal, the flow rate and the temperature of the inlet solution needs to be adjusted, as discussed in section 5 .
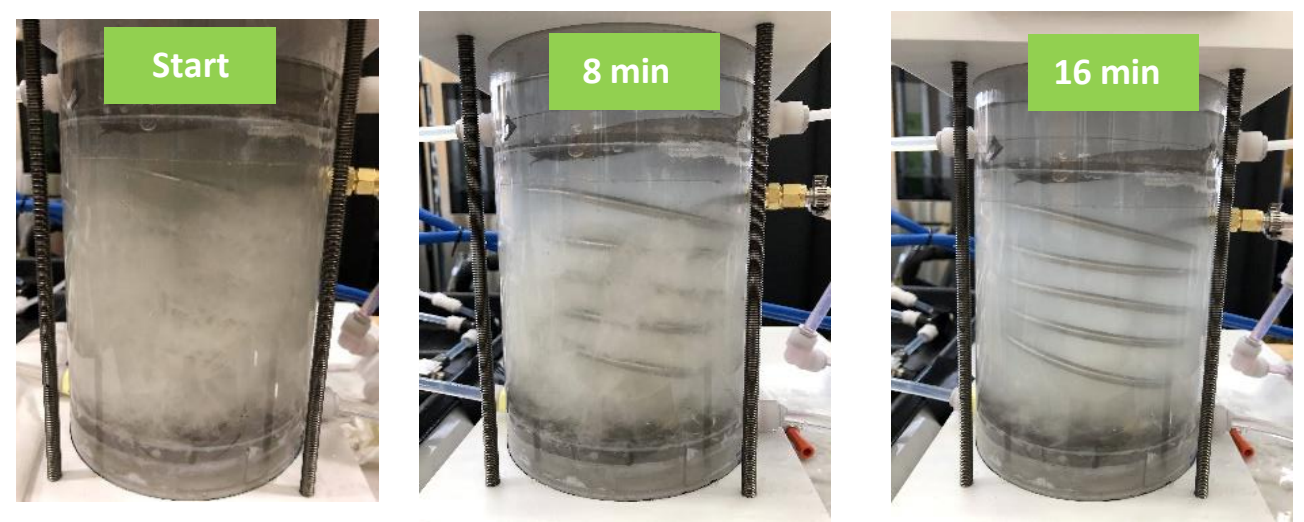

Figure 9. Dissolution process over time in the MSTB. 
(a)

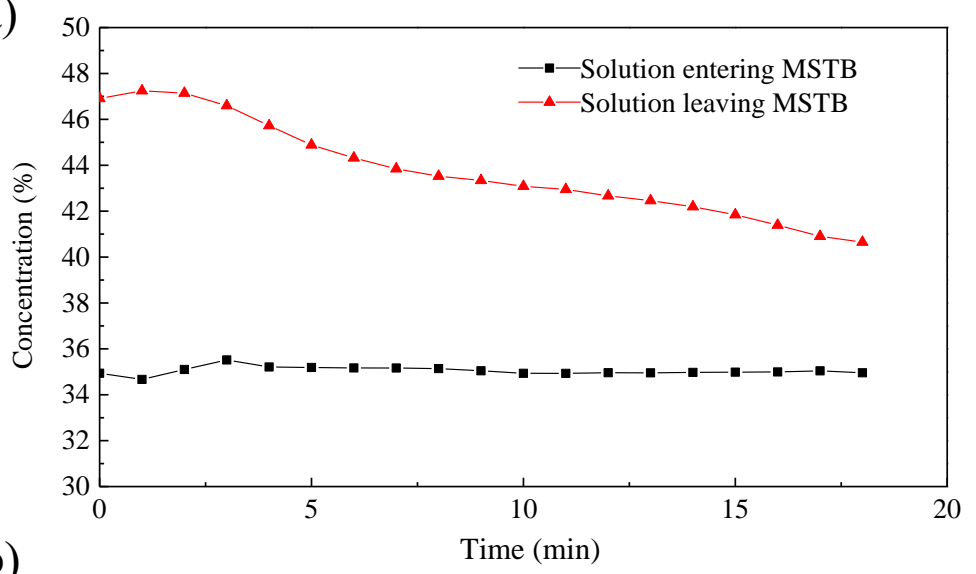

(b)

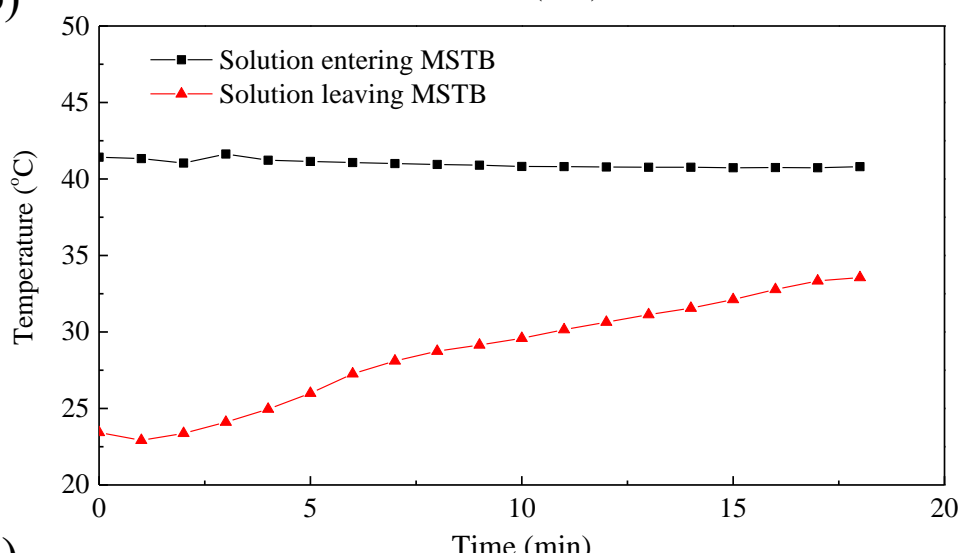

(c)

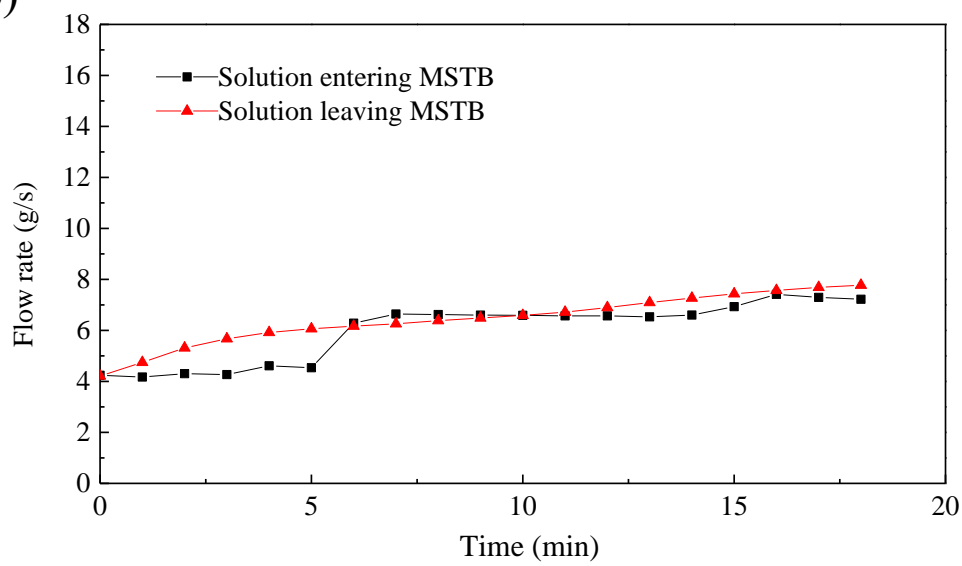

Figure 10. Measured data during dissolution process: (a) concentration of solution; (b) temperature of solution; (c) flow rate of solution. 


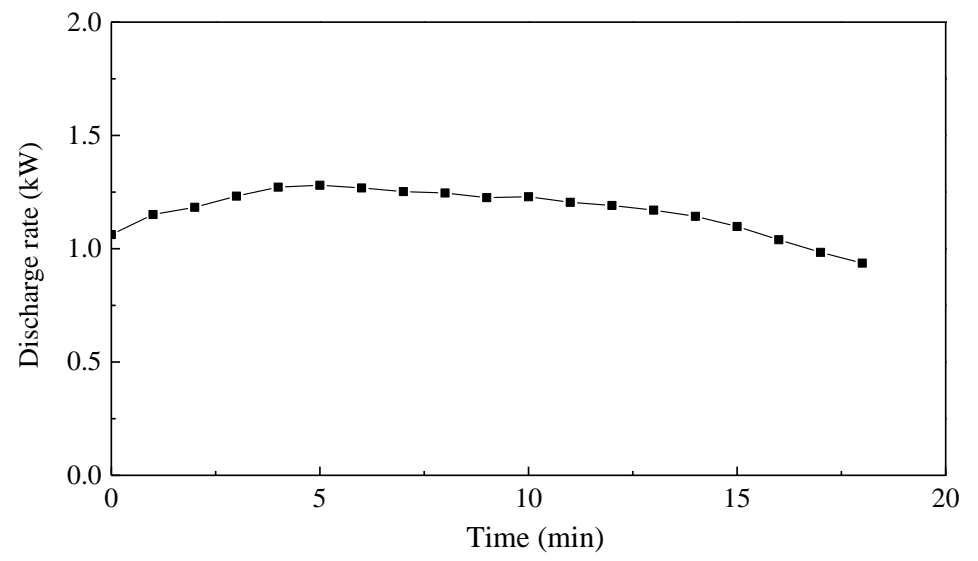

Figure 11. Calculated discharge rate of the MSTB based on dissolution test results.

\section{A PARAMETRIC STUDY OF CRYSTALLIZATION AND DISSOLUTION}

A parametric study was performed to investigate the impacts of several operating conditions on the crystallization and dissolution performance of the MSTB. The investigated operating conditions include solution flow rate and cooling water temperature for the crystallization performance; as well as solution flow rate, solution temperature, and internal solution circulation for the dissolution performance. ESD and the crystal fraction (the ratio of crystal mass to the mass in the MSTB) in the MSTB for the current study in the MSTB during the crystallization process were compared under various test conditions. The discharge rate of the dissolution process was also compared under various test conditions.

\subsection{CRYSTALLIZATION PERFORMANCE}

\subsubsection{Impacts of Solution Flow Rate}

The crystallization tests were conducted with three solution flow rates, $1.58 \mathrm{~g} / \mathrm{s}, 2.04 \mathrm{~g} / \mathrm{s}$, and $5.02 \mathrm{~g} / \mathrm{s}$, respectively, as listed in Table 5. Other test conditions remained nearly identical during these tests. The concentration and temperature of the inlet strong solution were kept at $50 \%$ and $\sim 60^{\circ} \mathrm{C}$, respectively, and the inlet cooling water temperature was maintained at $20.4{ }^{\circ} \mathrm{C}$.

Table 5. Test conditions of crystallization with different solution flow rates

\begin{tabular}{|c|c|c|c|c|c|}
\hline $\begin{array}{c}\text { Mass flow rate } \\
\text { of inlet } \\
\text { solution }(\mathbf{g} / \mathbf{s})\end{array}$ & $\begin{array}{c}\text { Concentration } \\
\text { of inlet } \\
\text { solution }(\%)\end{array}$ & $\begin{array}{c}\text { Temperature } \\
\text { of inlet } \\
\text { solution }\left({ }^{\circ} \mathrm{C}\right)\end{array}$ & $\begin{array}{c}\text { Flow rate of } \\
\text { cooling water } \\
(\mathrm{L} / \mathrm{min})\end{array}$ & $\begin{array}{c}\text { Temperature of } \\
\text { inlet cooling } \\
\text { water }\left({ }^{\circ} \mathrm{C}\right)\end{array}$ & $\begin{array}{c}\text { Temperature of } \\
\text { outlet cooling } \\
\text { water }\left({ }^{\circ} \mathrm{C}\right)\end{array}$ \\
\hline $\mathbf{1 . 5 8}$ & 50.1 & 60.6 & 0.90 & 20.4 & 21.8 \\
\hline $\mathbf{2 . 0 4}$ & 50.3 & 64.0 & 0.90 & 20.4 & 21.8 \\
\hline $\mathbf{5 . 0 2}$ & 49.6 & 61.1 & 0.89 & 20.4 & 21.8 \\
\hline
\end{tabular}


The ESDs resulting from these three tests are shown in Figure 12. It indicates that the ESD decreased with the increase of solution flow rate under the same cooling condition. In order to achieve a high ESD, a low solution flow rate is needed. The maximum ESD obtained from these tests was $981.8 \mathrm{~kJ} / \mathrm{kg}$ at a solution flow rate of $1.58 \mathrm{~g} / \mathrm{s}$. This exceeds our proposed target value of $900 \mathrm{~kJ} / \mathrm{kg}$.

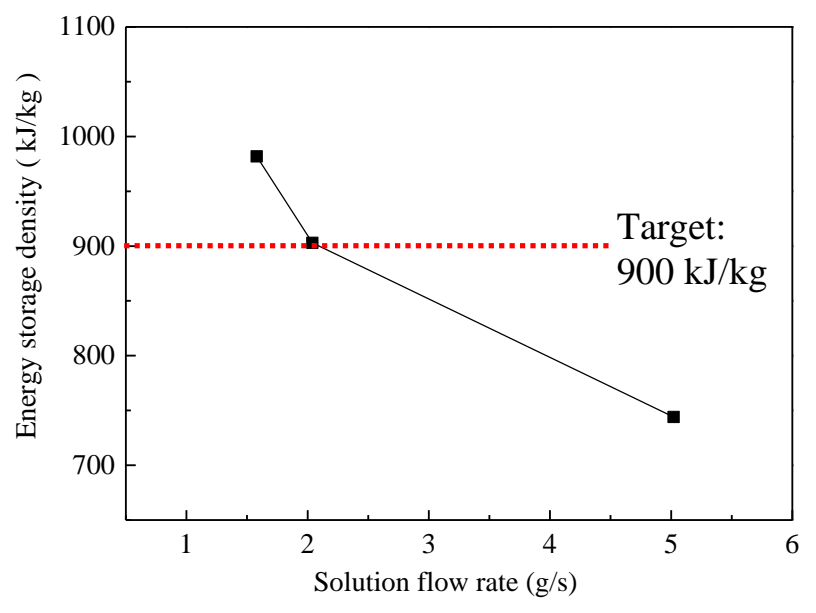

Figure 12. Energy storage densities with different solution flow rates.

Figure 13 presents the crystal fractions resulting from various solution flow rates. Similar to ESD, the crystal fraction also decreased with the increase of solution flow rate, and the maximum crystal fraction achieved in these tests was $51.1 \%$ when the solution flow rate was at $1.58 \mathrm{~g} / \mathrm{s}$. The crystal fraction dropped to only $12.1 \%$ when the solution flow rate was increased to $5.02 \mathrm{~g} / \mathrm{s}$.

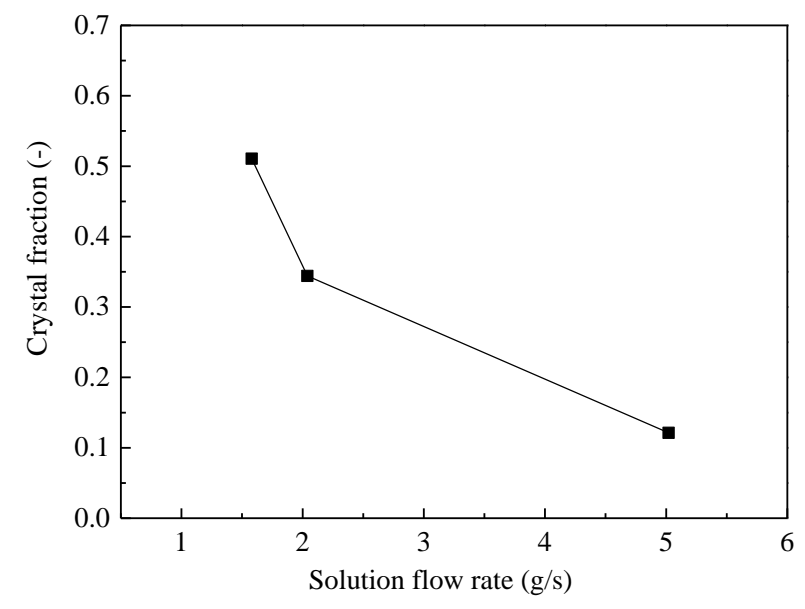

Figure 13. Crystal fractions with different solution flow rates.

Although a lower solution flow rate can result in a higher ESD, it also increases the risk of blockage in the piping system of the MSTB because the strong solution can quickly crystallize in the piping system when the solution flow is low. Therefore, an optimal solution flow rate needs to be identified in the future study to maximize the ESD while keeping the solution flowing continuously. 


\subsubsection{Impacts of Cooling Water Temperature}

The impacts of cooling water temperatures on the crystallization performance were investigated experimentally. The three test conditions are shown in Table 6. Three investigated cooling water temperatures were $11.1{ }^{\circ} \mathrm{C}, 20.4{ }^{\circ} \mathrm{C}$, and $29.7{ }^{\circ} \mathrm{C}$, respectively. Other test conditions remained identical for the three tests.

Table 6. Test conditions of crystallization with different cooling water temperatures

\begin{tabular}{|c|c|c|c|c|c|}
\hline $\begin{array}{c}\text { Mass flow rate } \\
\text { of inlet solution } \\
(\mathrm{g} / \mathrm{s})\end{array}$ & $\begin{array}{c}\text { Concentration } \\
\text { of inlet solution } \\
(\%)\end{array}$ & $\begin{array}{c}\text { Temperature of } \\
\text { inlet solution } \\
\left({ }^{\circ} \mathrm{C}\right)\end{array}$ & $\begin{array}{c}\text { Flow rate of } \\
\text { cooling water } \\
(\mathrm{L} / \mathrm{min})\end{array}$ & $\begin{array}{c}\text { Inlet } \\
\text { temperature of } \\
\text { cooling water } \\
\left({ }^{\circ} \mathbf{C}\right)\end{array}$ & $\begin{array}{c}\text { Outlet } \\
\text { temperature of } \\
\text { cooling water } \\
\left({ }^{\circ} \mathrm{C}\right)\end{array}$ \\
\hline 5.76 & 49.9 & 62.2 & 0.82 & $\mathbf{1 1 . 1}$ & 13.4 \\
\hline 5.02 & 49.6 & 61.1 & 0.89 & $\mathbf{2 0 . 4}$ & 21.8 \\
\hline 5.01 & 50.0 & 65.7 & 0.97 & $\mathbf{2 9 . 7}$ & 30.6 \\
\hline
\end{tabular}

The ESDs for these three tests are shown in Figure 14. As can be seen from this figure, ESD decreased with the increase of inlet cooling water temperature. When the inlet cooling temperature was increased from $11.1^{\circ} \mathrm{C}$ to $29.7^{\circ} \mathrm{C}$, the ESD decreased from $817.4 \mathrm{~kJ} / \mathrm{kg}$ to $714.1 \mathrm{~kJ} / \mathrm{kg}$. Similar results were also found for the crystal fractions, as shown in Figure 15. The crystal fraction decreased from $21.9 \%$ to $11.4 \%$ when the inlet cooling temperature was increased from $11.1{ }^{\circ} \mathrm{C}$ to $29.7^{\circ} \mathrm{C}$. The reason for this result is that the equilibrium concentration for crystallization in the MSTB increases at a higher cooling water temperature. Therefore, the driving force (the difference between the concentration of the strong solution and the equilibrium concentration for crystallization) for the crystallization is reduced.

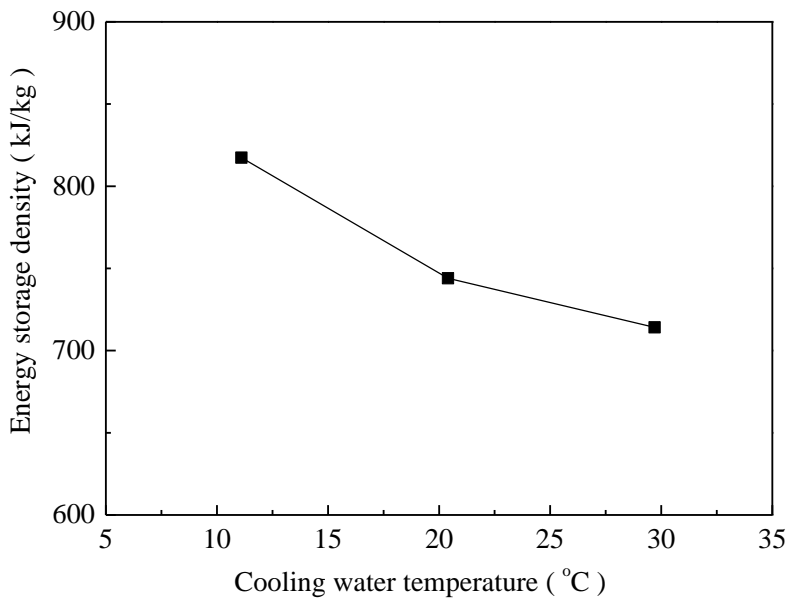

Figure 14. Crystal fraction resulting from various cooling water temperatures. 


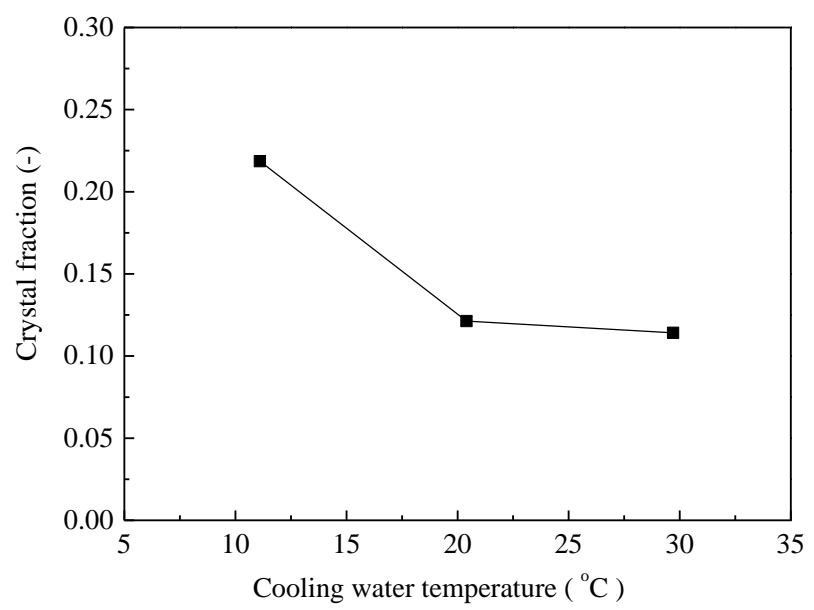

Figure 15. Energy storage densities resulting from various cooling water temperatures.

\subsubsection{Comparison of Energy Storage Density with Other Thermal Storage Technologies}

The maximum ESD obtained from the tests in this study is compared with other conventional thermal storage technologies ( $\mathrm{Li}$ and Wang 2012), as shown in Figure 16. The results indicate that the MSTB can achieve a much higher energy density than these thermal storage technologies, i.e. 2.8 times of ice storage, 5.6 times of PCM (paraffin), and 47 times of chilled water. Besides, unlike other thermal storage technologies, MSTB doesn't need to consider the problem of heat loss during storage. Thus, MSTB shows significant advantages over these conventional thermal storage technologies and promising application potential.

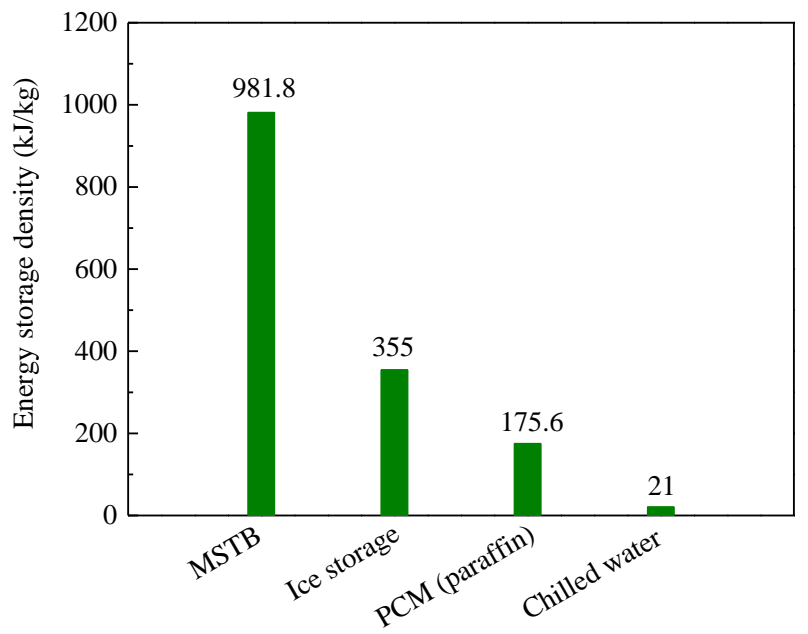

Figure 16. Comparison of energy storage densities between MSTB and other thermal storage technologies. 


\subsection{DISSOLUTION PERFORMANCE}

\subsubsection{Impacts of Solution Flow Rate}

The impacts of the solution flow rate were also studied for the dissolution process. Table 7 shows the three test conditions with different solution flow rates, i.e. $2.41 \mathrm{~g} / \mathrm{s}, 5.90 \mathrm{~g} / \mathrm{s}$, and $8.72 \mathrm{~g} / \mathrm{s}$, respectively. The concentration and temperature of the inlet solution remained nearly identical for the three tests.

Table 7. Dissolution test conditions with different solution flow rates

\begin{tabular}{|c|c|c|}
\hline $\begin{array}{l}\text { Mass flow rate of inlet solution } \\
(\mathrm{g} / \mathrm{s})\end{array}$ & Concentration of inlet solution (\%) & Temperature of inlet solution $\left({ }^{\circ} \mathrm{C}\right)$ \\
\hline 2.41 & 35.2 & 40.5 \\
\hline 5.90 & 35.1 & 40.9 \\
\hline 8.72 & 34.9 & 40.4 \\
\hline
\end{tabular}

The results of the discharge rate are shown in Figure 17. These results indicate that the maximum discharge rate increased with the increase of solution flow rate, as the mixing of solution and crystals in the MSTB was enhanced with a higher solution flow rate. When the solution flow rate was increased from $2.41 \mathrm{~g} / \mathrm{s}$ to $8.72 \mathrm{~g} / \mathrm{s}$, the maximum discharge rate increased from $0.95 \mathrm{~kW}$ to $1.5 \mathrm{~kW}$, while the time needed for totally dissolving the crystals reduced from $28 \mathrm{~min}$ to $15 \mathrm{~min}$. The higher of the solution flow rate, the shorter and less stable the discharge process would be. It is because the total amount of salt crystals stored in the MSTB was fixed, thus a higher discharge rate at the beginning resulted in a faster decay of the discharge rate. Therefore, both the discharge rate and the needed duration should be accounted for when determining the size and solution flow rate of an MSTB system.
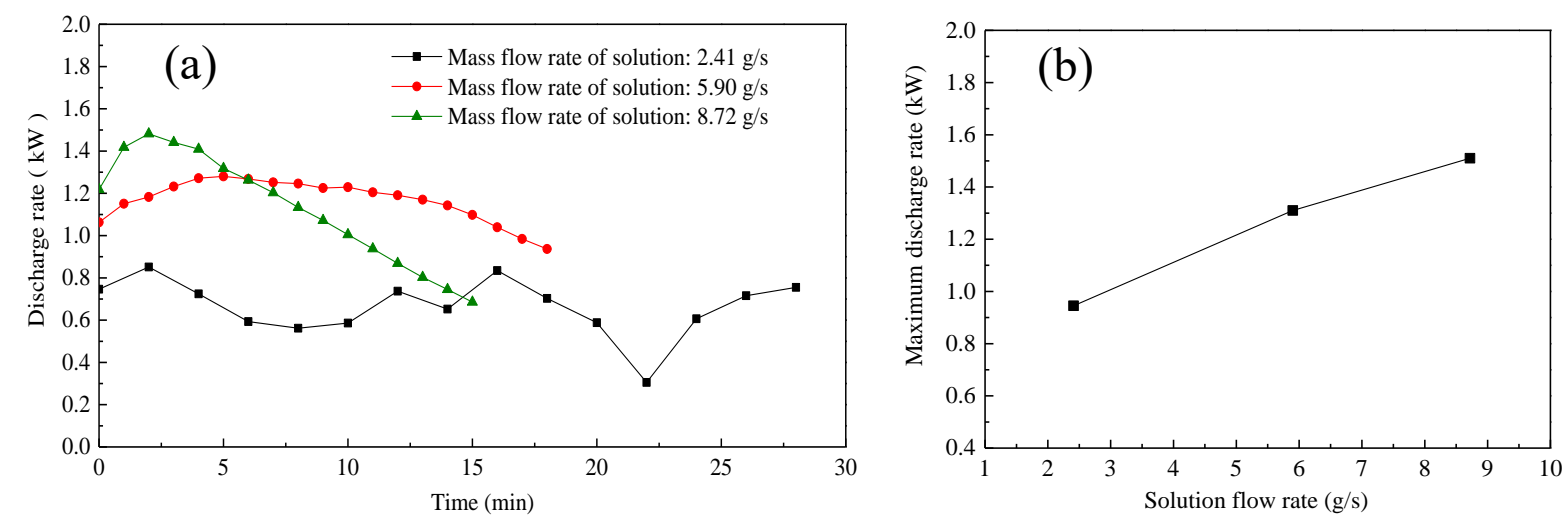

Figure 17. Discharge performance with different solution flow rates: (a) discharge rate over time; (b) maximum discharge rate.

\subsubsection{Impacts of Solution Temperature}

Two test conditions with different inlet solution temperatures, i.e. $40.9^{\circ} \mathrm{C}$ and $50.0^{\circ} \mathrm{C}$, are shown in Table 8 . The concentration and mass flow rate of the inlet solution were kept constant for the two tests. Figure 18 
indicates that the higher the inlet solution temperature, the higher the maximum discharge rate. The maximum discharge rate reached $1.79 \mathrm{~kW}$ when the inlet solution temperature was $50.0^{\circ} \mathrm{C}$, which achieves the targeted discharge rate of $1.75 \mathrm{~kW}$, but it didn't last for a long time due to the limited energy capacity of the MSTB. Since the $50.0{ }^{\circ} \mathrm{C}$ solution temperature is higher than the temperature of a $\mathrm{LiCl}$ solution leaving a desiccant cooling system, usually ranging from 30 to $35^{\circ} \mathrm{C}$, pre-heating is thus needed. Renewable or low-grade energy (such as the low-temperature geothermal energy) can be used to pre-heat of the solution.

Table 8. Dissolution test conditions with different inlet solution temperatures

\begin{tabular}{|c|c|c|}
\hline $\begin{array}{c}\text { Mass flow rate of inlet solution } \\
(\mathrm{g} / \mathrm{s})\end{array}$ & $\begin{array}{c}\text { Concentration of inlet solution }(\%) \\
\text { Temperature of inlet solution }\left({ }^{\circ} \mathbf{C}\right)\end{array}$ \\
\hline 5.90 & 35.1 & $\mathbf{4 0 . 9}$ \\
\hline 5.52 & 35.1 & $\mathbf{5 0 . 0}$ \\
\hline
\end{tabular}
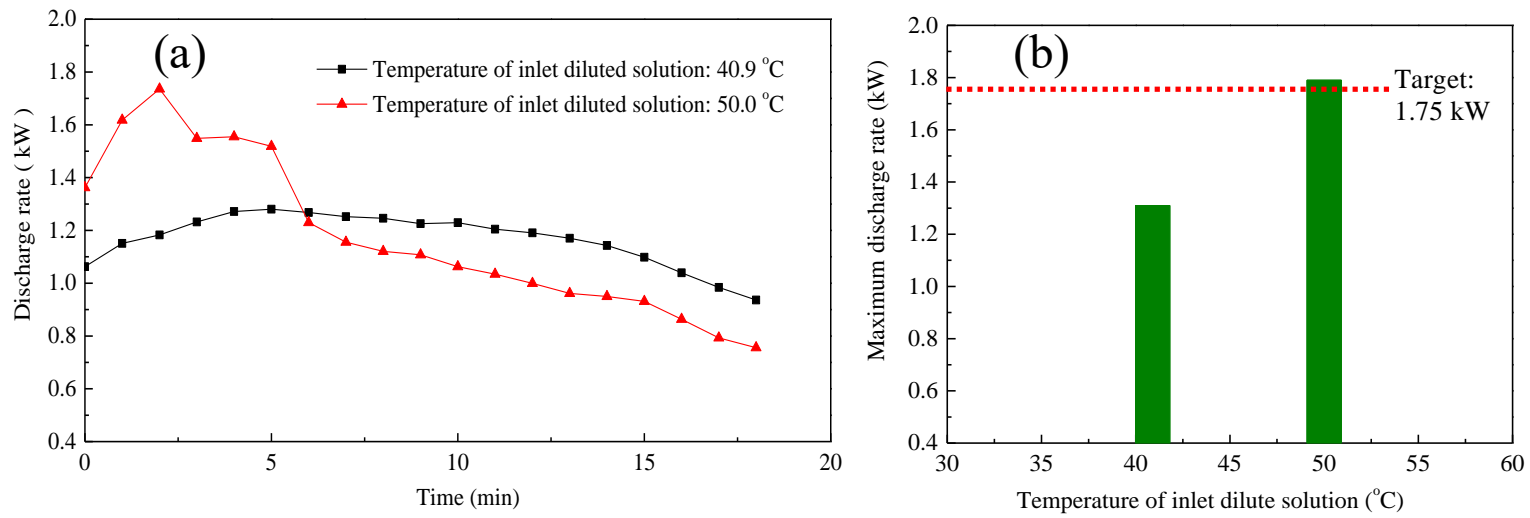

Figure 18. Discharge performance with different inlet solution temperatures: (a) discharge rate over time; (b) maximum discharge rate.

\subsubsection{Impacts of Internal Solution Circulation}

As presented in section 5.2.1, a higher solution flow rate would result in a higher discharge rate because the mixing between the diluted solution and the salt crystals is enhanced. However, a higher solution flow rate may result in a higher pumping power due to a high pressure drop in the solution piping system. If the mixing is enhanced by using a small pump to circulate the solution within the MSTB, the power consumption may be reduced. The impact of internal solution circulation on the dissolution performance was investigated. The two test conditions with and without internal solution circulation are shown in Table 9.

Table 9. Dissolution test conditions of with/without internal solution circulation

\begin{tabular}{|c|c|c|}
\hline $\begin{array}{l}\text { Mass flow rate of inlet solution } \\
(\mathrm{g} / \mathrm{s})\end{array}$ & Concentration of inlet solution (\%) & Temperature of inlet solution $\left({ }^{\circ} \mathrm{C}\right)$ \\
\hline 2.41 & 35.2 & 40.5 \\
\hline 2.56 & 35.0 & 40.8 \\
\hline
\end{tabular}


Figure 19 shows a comparison of the discharge rates of the two tests. These results indicate that the maximum discharge rate increased from $0.95 \mathrm{~kW}$ to $1.31 \mathrm{~kW}$ (a $38 \%$ increase) by adding internal circulation in the MSTB while keeping the inlet solution flow rate intact. It also means that, for maintaining the same discharge rate, a lower inlet solution flow rate can be used if the solution is circulated in the MSTB, which may lead to a lower pumping power consumption of the MSTB system.
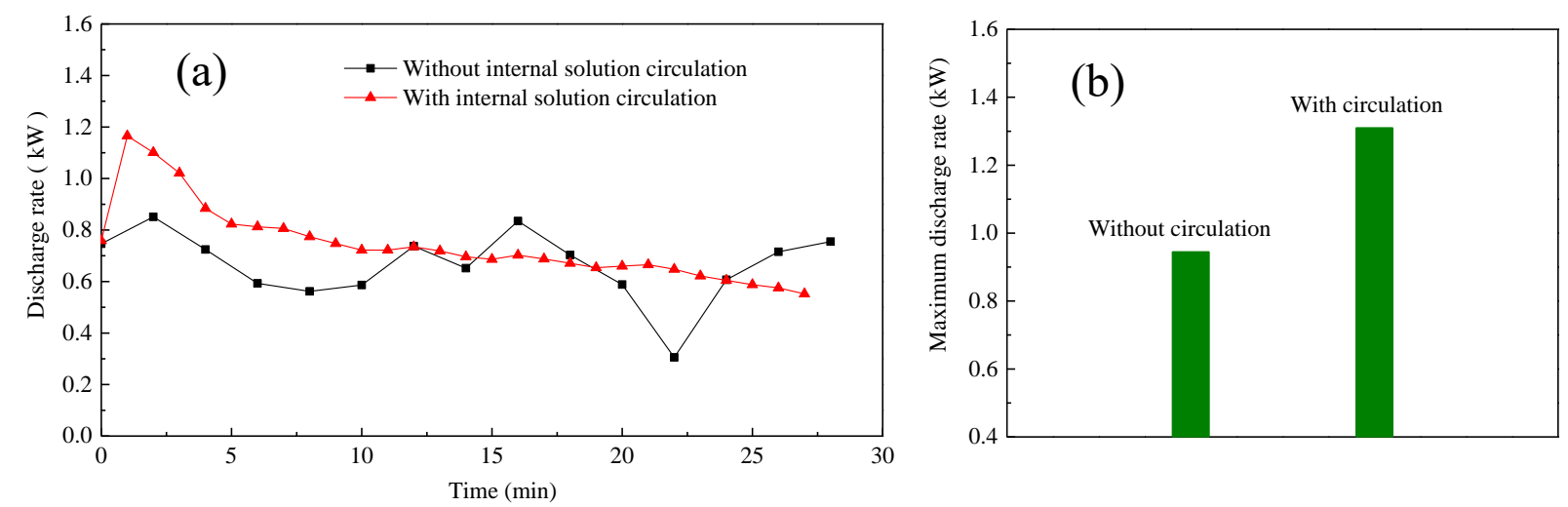

Figure 19. Discharge performance with and without internal solution circulation: (a) discharge rate over time; (b) maximum discharge rate. 


\section{CONCLUSIONS AND PLAN FOR FUTURE WORK}

This project involved conducting an experimental study on the characteristics of crystallization and dissolution in an MSTB. $\mathrm{LiCl}$ aqueous solution was used for energy storage. Crystallization by active cooling and dissolution in the MSTB was tested in a dedicated experimental apparatus. The methods for calculating ESD during the crystallization process and discharge rate during the dissolution process based on the measured performance data were derived and used to evaluate the performance of the crystallization and dissolution of the MSTB. A parametric study was conducted to investigate the impacts of several operating conditions on crystallization and dissolution performance.

The crystallization test results show that the current design of the MSTB is effective for generating salt crystals using a $\mathrm{LiCl}$ solution with $50 \%$ concentration (in mass) and a heat sink temperature below $30^{\circ} \mathrm{C}$. The entire MSTB, with an occupied volume of $4.3 \mathrm{~L}$, can be filled with salt crystals within 50 min at the operating conditions investigated in this study. The mass of generated crystal varies from 0.688 to $3.164 \mathrm{~kg}$ at the operating conditions investigated in this study, resulting in the crystal fraction varying from 11.4 to $51.1 \%$ and the stored energy varying from 5.678 to $10.229 \mathrm{MJ}$ (i.e., $1.577-2.841 \mathrm{kWh}$ ). The dissolution test results show that the $\mathrm{LiCl}$ hydrate crystals in the MSTB can be fully dissolved in 15-28 min, depending on operating conditions.

The ESD and crystal fraction increase with a decrease in solution flow rate and cooling water temperature, while the discharge rate (i.e., latent cooling capacity for dehumidifying air) increases with the solution flow rate and temperature of the diluted solution. By introducing an internal circulation in the MSTB using a small circulator, the discharge rate can be increased from 0.95 to $1.31 \mathrm{~kW}$, a $38 \%$ increase.

The maximum ESD achieved in the crystallization tests was $981.8 \mathrm{~kJ} / \mathrm{kg}$, and the maximum discharge rate achieved in the dissolution tests was up to $1.79 \mathrm{~kW}$. Both of these performances exceed the targeted goals of this project (i.e., $900 \mathrm{~kJ} / \mathrm{kg}$ energy density and $1.75 \mathrm{~kW}$ latent cooling capacity). Project results demonstrate the MSTB system's technical feasibility and prove that the MSTB can achieve a higher energy density than other thermal storage technologies.

The following research and development work is recommended to move from the proved concept to practical implementation of MSTB systems:

- Improve the MSTB's heat exchanger design to increase the ESD and discharge rate.

- Develop a mathematic model of the MSTB and integrate it with models of other components to simulate the performance of the MSTB system and develop the control strategy of the MSTB system to enable flexible building load and shift electric demand.

- Assess the benefits and costs of using the MSTB to enable flexible building load, and compare it with other thermal energy storage systems for shifting/leveling electric load profile of buildings.

- Optimize the design and operating conditions to maximize the cost-effectiveness of the MSTB system for the most promising markets. 


\section{REFERENCES}

Cabeza, L. F., Castell, A., Barreneche, C. D., De Gracia, A., and Fernández, A. I. "Materials used as PCM in thermal energy storage in buildings: a review." Renewable and Sustainable Energy Reviews, 15(3), (2011), 1675-1695.

Conde, M. R. "Properties of aqueous solutions of lithium and calcium chlorides: formulations for use in air conditioning equipment design." International Journal of Thermal Sciences, 43, (2004), 367-82.

DOE. "Direct Use of Geothermal Energy." Available at http://energy.gov/eere/geothermal/direct-usegeothermal-energy, (2015).

Fumey, B., Weber, R., Gantenbein, P., Daguenet-Frick, X., Williamson, T., and Dorer, V. "Development of a closed sorption heat storage prototype." Energy Procedia, 46, (2014), 134-141.

Helden, W.V., et al. CREATE project. https://www. createproject.eu, (2015).

Koll, J., Helden, W.V., and Fumey, B. COMTES project. http://comtes-storage.eu/, (2015).

Li, C., and Wang, R.Z. "Building integrated energy storage opportunities in China." Renewable and Sustainable Energy Reviews, 16(8), (2012), 6191-6211.

Liu, X., Yang, Z., Gluesenkamp, K. R., and Momen, A. M. "A Technical and Economic Analysis of an Innovative Two-Step Absorption System for Utilizing Low-Temperature Geothermal Resources to Condition Commercial Buildings." Technical report no. ORNL/TM-2015/655. Oak Ridge, TN: Oak Ridge National Laboratory (2015).

Nelson, J. E. B., Balakrishnan, A. R., and Murthy, S. S. "Parametric studies on thermally stratified chilled water storage systems.” Applied Thermal Engineering, 19(1), (1999), 89-115.

N'Tsoukpoe, K. E., Le Pierrès, N., and Luo, L. "Experimentation of a $\mathrm{LiBr}-\mathrm{H} 2 \mathrm{O}$ absorption process for long-term solar thermal storage: Prototype design and first results.” Energy, 53, (2013), 179-198.

N'Tsoukpoe, K. E., Perier-Muzet, M., Le Pierres, N., Luo, L., and Mangin, D. "Thermodynamic study of a $\mathrm{LiBr}-\mathrm{H} 2 \mathrm{O}$ absorption process for solar heat storage with crystallisation of the solution." Solar Energy, 104, (2014), 2-15.

OIT Geo-Heat Center. "Geothermal Direct-Use Case Studies.” (2005). Accessed May 12, 2019. https://www.oit.edu/orec/geo-heat-center/case-studies. Accessed: 5/12/2019

Sögütoglu, L. C., et al. "In-depth investigation of thermochemical performance in a heat battery: Cyclic analysis of $\mathrm{K}_{2} \mathrm{CO}_{3}, \mathrm{MgCl}_{2}$ and $\mathrm{Na}_{2} \mathrm{~S}$." Applied Energy, 215, (2018), 159-173.

US Energy Information Administration. “Annual Energy Outlook 2018.” (2018), Washington, DC. https://www.eia.gov/outlooks/aeo/2.

Weber, R, and V. Dorer. "Long-term heat storage with NaOH." Vacuum, 82(7), (2008), 708-716.

Yang, Z., Liu, X., Gluesenkamp, K. R., and Momen, A. M. "A Preliminary Study on Innovative Absorption Systems that Utilize Low-Temperature Geothermal Energy for Air-Conditioning Buildings." 16th International Refrigeration and Air Conditioning Conference at Purdue, Purdue University, West Lafayette, IN, (July 11-14, 2016).

Yang, Z., Liu, X., et al. "Transported Low Temperature Geothermal Energy for Thermal End Uses-Final Report." Technical report o. ORNL/TM-2016/658. Oak Ridge, TN: Building Technologies Research and Integration Center, Oak Ridge National Laboratory (2016). 